\title{
Metallothionein Gene Family in the Sea Urchin Paracentrotus lividus: Gene Structure, Differential Expression and Phylogenetic Analysis
}

\author{
Maria Antonietta Ragusa ${ }^{1, *}$, Aldo Nicosia ${ }^{2}$, Salvatore Costa ${ }^{1}$, Angela Cuttitta ${ }^{2}$ and \\ Fabrizio Gianguzza ${ }^{1}$ \\ 1 Department of Biological, Chemical, and Pharmaceutical Sciences and Technologies, University of Palermo, \\ 90128 Palermo, Italy; salvatore.costa@unipa.it (S.C.); fabrizio.gianguzza@unipa.it (F.G.) \\ 2 Laboratory of Molecular Ecology and Biotechnology, National Research Council-Institute for Marine and \\ Coastal Environment (IAMC-CNR) Detached Unit of Capo Granitola, Torretta Granitola, 91021 Trapani, \\ Italy; aldo.nicosia@iamc.cnr.it (A.N.); angela.cuttitta@iamc.cnr.it (A.C.) \\ * Correspondence: maria.ragusa@unipa.it; Tel.: +39-091-238-97401
}

Academic Editor: Masatoshi Maki

Received: 6 March 2017; Accepted: 5 April 2017; Published: 12 April 2017

\begin{abstract}
Metallothioneins (MT) are small and cysteine-rich proteins that bind metal ions such as zinc, copper, cadmium, and nickel. In order to shed some light on MT gene structure and evolution, we cloned seven Paracentrotus lividus MT genes, comparing them to Echinodermata and Chordata genes. Moreover, we performed a phylogenetic analysis of 32 MTs from different classes of echinoderms and 13 MTs from the most ancient chordates, highlighting the relationships between them. Since MTs have multiple roles in the cells, we performed RT-qPCR and in situ hybridization experiments to understand better MT functions in sea urchin embryos. Results showed that the expression of MTs is regulated throughout development in a cell type-specific manner and in response to various metals. The MT7 transcript is expressed in all tissues, especially in the stomach and in the intestine of the larva, but it is less metal-responsive. In contrast, MT8 is ectodermic and rises only at relatively high metal doses. MT5 and MT6 expression is highly stimulated by metals in the mesenchyme cells. Our results suggest that the P. lividus MT family originated after the speciation events by gene duplications, evolving developmental and environmental sub-functionalization.
\end{abstract}

Keywords: metallothionein; multigene families; evolution; metal; echinoderms; embryonic development; gene expression

\section{Introduction}

Metallothioneins (MTs) represent a superfamily of widespread proteins existing of many organisms, ranging from prokaryotes to vertebrates. The superfamily consists of constitutive and stress-inducible members, with variable masses. It is rich in cysteine (Cys) residues (nearly $30 \%$ of their amino acid composition), and the residues constitute the metal-thiolate clusters [1]. MTs possess great affinity for both essential (zinc, copper, selenium) and xenobiotic (cadmium, lead, mercury) metals, binding them through specific Cys-Cys and Cys-Xxx-Cys motifs. Usually, Cys-Cys motifs are located in the C-terminal moiety (also known as $\alpha$-domain), and Cys-Xxx-Cys motifs map the $\mathrm{N}$-terminal half (or $\beta$-domain). MTs are known to exhibit a plethora of biological functions, including protection against metal toxicity, control of oxidative stress and regulation of physiological homeostasis [2-5]. In addition to their central role as metal scavengers, MTs are also involved in a number of cellular activities, including cell proliferation [6], differentiation [7,8], apoptosis and immune response $[9,10]$. Finally, MTs have also gained attention in biomedical studies, due to their proposed involvement in 
cancer and neurological diseases [11-15]. MTs have been classified into different families on the basis of structural features and arrangement of Cys motifs [16,17]. Nevertheless, the large number of MTs discovered so far clearly demonstrates the existence of intermediate isoforms, making the classification of MTs very challenging.

Indeed, mechanisms of duplication, convergence and functional differentiation have created a complex evolutionary history, which is difficult to define [18-20].

Through the years, several studies exploring MTs in different organisms (from vertebrates, such as humans, rodents, aves, and amphibians, to invertebrates, such as molluscs, nematodes and insects) have been reported [17].

Deuterostome superphylum diversified around 510 million years ago (Myr), into echinoderms, hemichordates, tunicates and vertebrates. The Echinodermata phylum includes sea stars (Asteroidea), sea urchins and sand dollars (Echinoidea), brittle stars (Ophiuroidea), sea cucumbers (Holothuroidea) and sea lilies (Crinoidea). Thus, Echinoderms represent a very fascinating phylum since they are closely related to Chordates.

Among Echinodermata, sea urchin MT homologues have been identified in Strongylocentrotus purpuratus [21], Lytechinus pictus [22], Sterechinus neumayeri and Sphaerechinus granularis [23], revealing an unusual distribution of Cys motifs. Additionally, the three-dimensional structure analysis of S. purpuratus MTA revealed that this unusual Cys motif distribution caused an inverted architecture of the $\alpha$ - and $\beta$-domains with respect to vertebrate structure [24]. Previously, we reported the identification of five different MT homologues (PlMT4-8) from the Mediterranean sea urchin species Paracentrotus lividus. Two family members, PlMT7 and PlMT8, are constitutively expressed and upregulated in response to cadmium treatment, whereas PIMT4, PIMT5 and PIMT6 appear to be specifically switched-on after cadmium exposure [25].

Herein, with the aim of better understanding the evolutionary relationships, functional variety, and the utilization of MTs during development, the gene organisation of P. lividus MTs was analysed and their mRNA expression patterns were unveiled. Particularly, we determined the expression profiles and the spatial patterns of $P$. lividus MT transcripts during development and after metal treatments.

Moreover, exploiting the advances in homologues detection and homology protein modelling, theoretical structure calculation methods were applied. Evolutionary perspectives on MTs in deuterostomes were accomplished combining phylogeny and gene features.

\section{Results}

\subsection{The Metallothionein Genes of P. lividus}

The availability of large-scale transcriptional data sets for the Mediterranean sea urchin P. lividus allowed us to carry out a transcriptome survey for a comprehensive identification of the MT homologues. We performed BLASTN and TBLASTN searches using MT CDNA sequences previously cloned as queries [25] and a clustering analysis of MT expressed sequence tags (EST) retrieved. No MT4, MT5 or MT6 sequences were found in the databases, confirming their low expression. Collectively, two MT7 transcript populations differing in length and three MT8 different populations were retrieved. Their identification was checked manually and the matching sequences were reconfirmed by comparative analysis. These results suggest that MT7 transcripts may derive from a single gene by alternative splicing or multiple polyadenylation signals or even from two different genes. Moreover, it is possible to hypothesise the presence of at least three MT8 genes.

In order to identify and isolate the expressed MT genes, total genomic DNA from P. lividus sperm was extracted and amplified using primer pairs selected as described in Materials and Methods. The amplified products were cloned, sequenced and analysed. Four genomic clones, coding for MT4, MT5, MT6, MT7 and three diverse clones corresponding to MT8 (named MT8a, b, c) were obtained.

The comparison between cDNA and genomic sequences revealed that the transcription units are composed by four exons interrupted by three introns and are different in length. The first two introns 
interrupt the coding sequence after the first nucleotide of the codon (phase-1), the last intron is located in the $3^{\prime}$ UTR. The gene structures of the P. lividus MT genes are represented in Figure 1. All of them possess canonical splicing sites, identified at $5^{\prime}$-end by GT and at $3^{\prime}$-end by AG consensus sequences. Moreover, a comparative analysis between P. lividus and S. purpuratus MT genes (Strongylocentrotid diverged 35-50 Myr from the Parechinidae [26]) showed that all possess the same structure [27]. Nevertheless, intron lengths and sequences are different between all homologous genes.

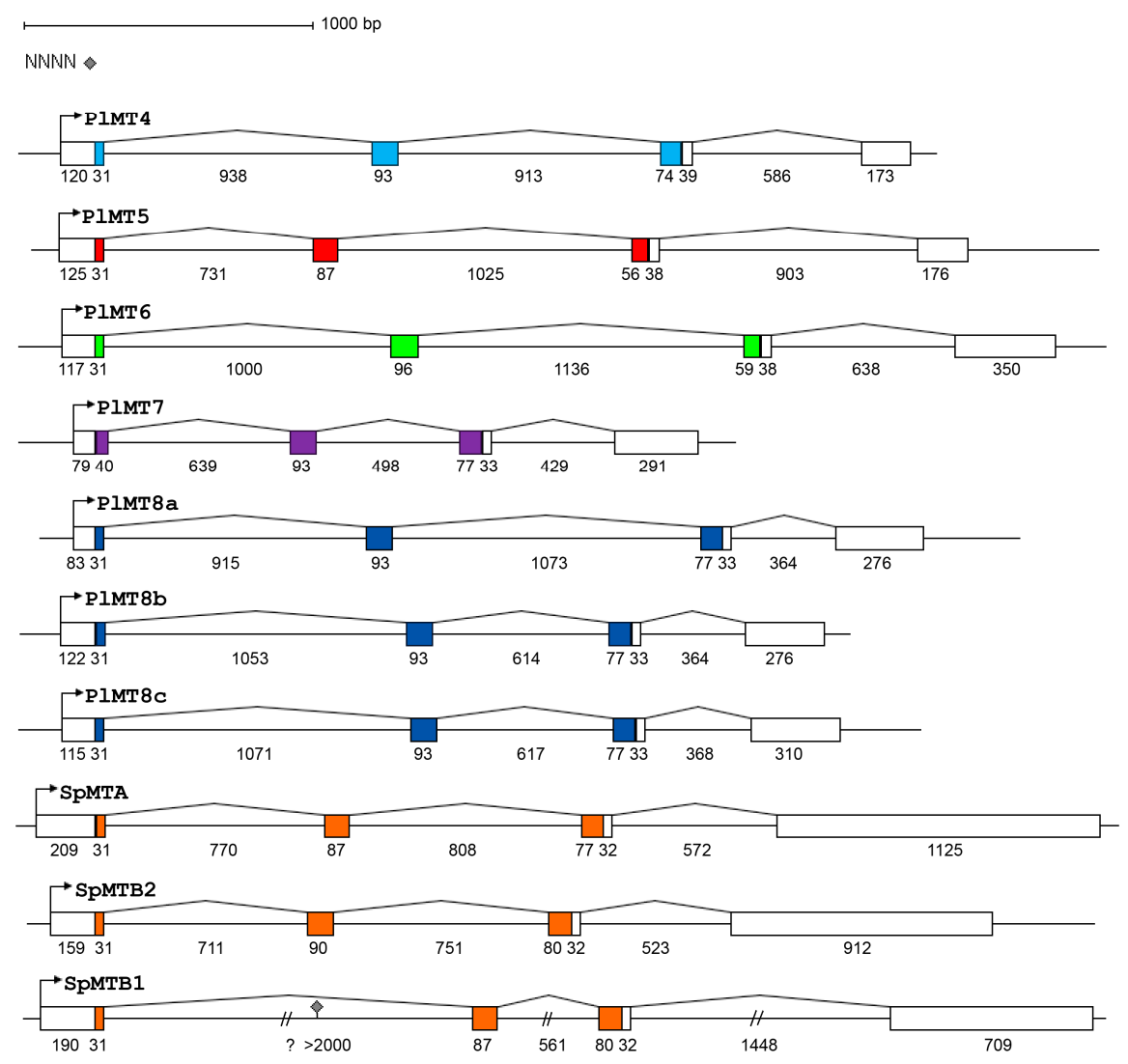

Figure 1. Schematic gene structures of the Paracentrotus lividus and Strongylocentrotus purpuratus metallothioneins (MTs; drawn to scale). The bent arrows indicate the putative transcription start sites (TSS). Numbers under schemes indicate base pair numbers of exons and introns; boxes represent exons: white boxes indicate untranslated regions, and coding regions are coloured. The grey diamond indicates one $\mathrm{N}$ stretch in the SPMTB1 intron.

In silico predictions showed two polyadenylation sites in the MT7 gene (score 0.876 and 0.898 ) which could explain the presence of two MT7 mRNA species different in length during embryo development.

$M T 8 b$ and MT8c showed approximately the same length and $94 \%$ identity. Both genes contain 136 additional bps in the first intron and a 476-bp deletion in the second intron with respect to MT8a. In alignable sequences, the identity between MT8a and MT8b is $97 \%$, higher than the identity with MT8c (93\%). The MT8a and MT8b-expressed sequences show $98 \%$ of identity between them and $95 \%$ with $M T 8 c$, differing for the presence of a simple AT-rich region in the $3^{\prime}$ UTR.

\subsection{Predicted 3D Structural Model of P. lividus MTs}

On the basis of the computational analysis, we determined the key features of MT homologues in P. lividus. As previously highlighted [25], only MT7 and MT8 follow the MT family 4 rule (Echinoidea: IPR001396; [17]): P-D-x-K-C-[V,F]-C-C-x(5)-C-x-C-x(4)-C-C-x(4)-C-C-x(4,6)-C-C located near the $\mathrm{N}$ terminus. Other isoforms instead have divergent amino acid sequences and in particular MT4 and MT6 have a cysteine pattern that is slightly different. 
The MTs are organized in a N-domain and a C-domain bearing a pattern of conserved Cys residues required for binding bivalent metal ions [17]. As occurred in S. purpuratus MTs, Cys-Cys motifs, typical of the C-domain in mammals, are located in the $\mathrm{N}$-domain. Multiple sequence alignment (MSA) analysis of P. lividus and S. purpuratus MTs (Figure 2) showed that, in addition to conserved Cys pattern, the accepted amino acids substitutions do not always possess similar physical chemical features. We argue that such changes might not support the same structure and could alter biochemical properties, allowing MT involvement in different pathways.

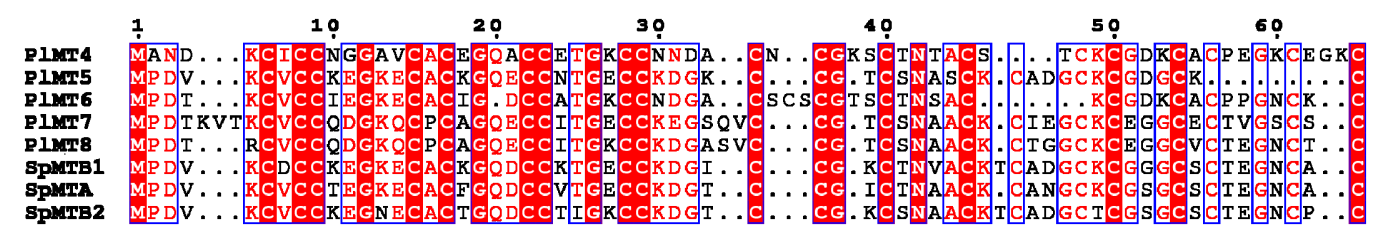

Figure 2. Multiple sequence alignment (MSA) of P. lividus and S. purpuratus MT sequences. Identities and conservative substitutions are in red font. Red shading represents identity among all sequences. Dots denote gaps. Non-conservative substitutions are in black font.

In order to obtain some indication on structure changes, we computed the secondary elements and derived the 3D structures of P. lividus MTs (PIMTs). Different templates were selected to model the Mediterranean sea urchin MTs, on the basis of heuristics to maximise confidence, percentage identity and alignment coverage. If required, insertions were modelled ab initio. The generated models were validated by assessing Ramachandran plot analysis and the percentage of residues in the favoured/allowed region ranged from $91 \%$ to $96 \%$. In a manner similar to those described in previous studies, PIMTs mainly consisted of coils and turns; while different numbers of helical structures were computed (three $\alpha$-helices in MT4, MT6 and MT8, two and four $\alpha$-helices in MT5 and MT7, respectively).

Generally, the global structure of each protein resembled that of MTs from other organisms: two domains connected by a flexible hinge. However, MT4 and MT5 proteins appeared to be more compact than MT6, 7 and 8 (Figure 3). The relative solvent accessibility (RSA) of the Cys residues in the folded protein was also calculated. Based on RSA values, sea urchin MTs exhibited a similar pattern of solvent accessibility in the Cys, as such residues were found to mainly adopt a buried (RSA $<0.1$ ) or intermediate $(0.1<\mathrm{RSA}<0.4)$ conformation. Conversely, exposed and highly exposed residues $(0.4<$ RSA $<1$ and RSA $>1$ respectively) were found to be strongly underrepresented (Figure 3).
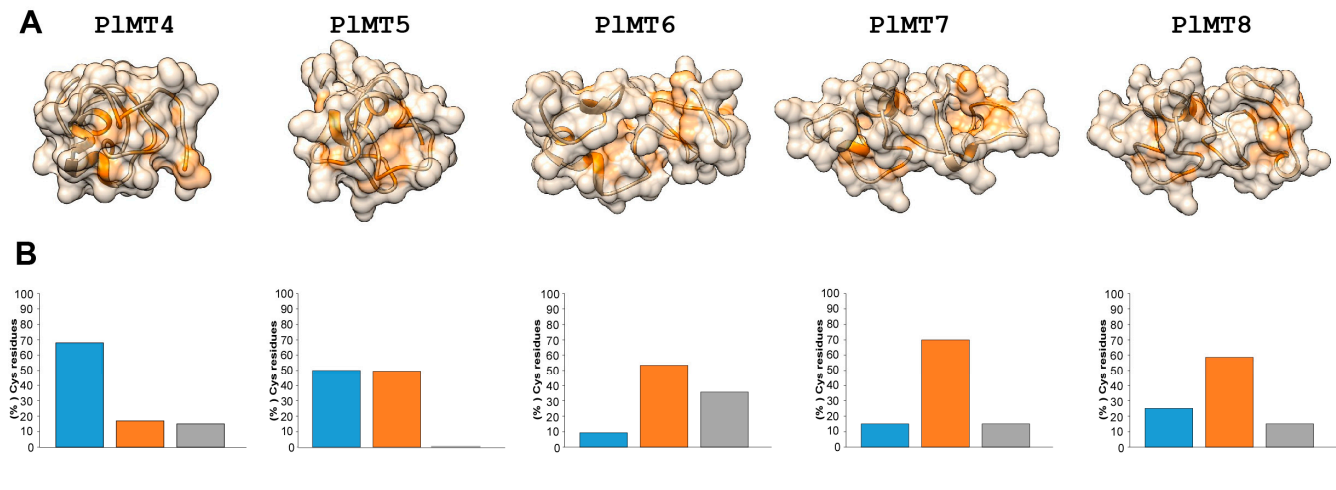

$$
\begin{array}{lc}
0.1<\mathrm{RSA}<0.4 & 0.4<\mathrm{RSA}<1 \\
\text { Intermediate } & \text { Exposed }
\end{array}
$$

Figure 3. Ribbon diagrams and surface representations of PIMTs. (A) General overview of the 5 PlMTs generated by homology modelling with cysteine residues labelled in orange. As far as possible, $\mathrm{N}$-terminal is on the left and C-terminal is on the right; (B) Relative solvent accessibility (RSA) calculated as percentage of corresponding cysteine residues in each protein. 
According to the structural features of S. purpuratus MTs (SpMTs) [24] and in silico protein-ligand binding site recognition, possible metal-thiolate cluster structures of PIMTs were predicted. The absence of specific Cys residues in the C-domain of MT4, 5 and 6 as well as the presence of an additional Cys residue in the N-domain of MT6 raise the possibility that these homologues were likely prone to accept variations in metal binding without modifications of the total number of bonded divalent cations. Elsewhere, the $\mathrm{N}$ - and C-domains of these homologues may likely encompass different metal-thiolate clusters.

As shown in Figure 4, four and three metal-thiolate clusters were identified in the N-and C-domain respectively of MT7 and MT8. The cluster connectivities between the cysteine thiolate groups and the metal ions in the N- and C-domains of MT7 and MT8 were compared with the well-defined SpMTA. Thus, algorithms to superimpose the polypeptide backbones from these homologues were applied and analogous spatial arrangements of Cys residues among structures and related metal-sulfur clusters were retrieved (Figure 4).

A

$\alpha$

$\beta$

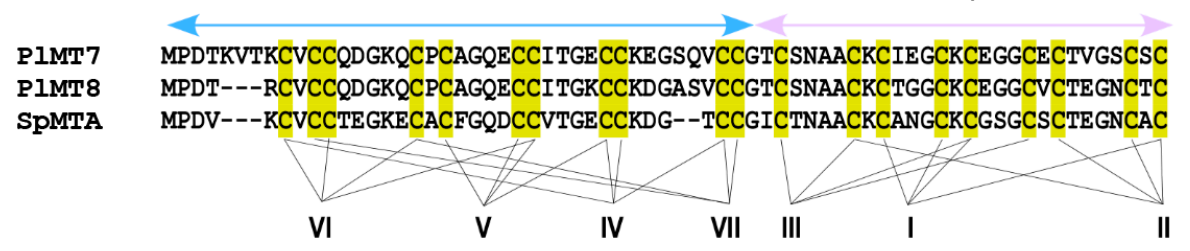

B
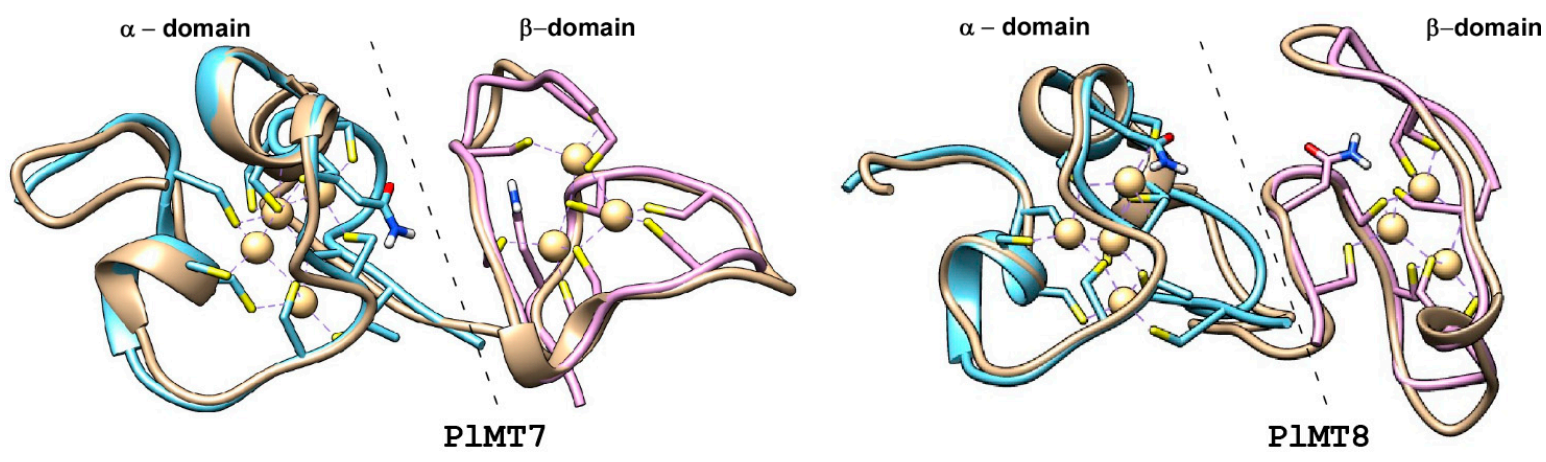

Figure 4. Metal-thiolate cluster analysis and structural similarities between PIMT7, PIMT8 and SpMTA. (A) Cluster connectivities between the cysteine thiolate groups and the metal ions in the $\alpha$ - and $\beta$-domains of the sea urchin MTs. Cys residues are boxed in yellow, while the metal ions are specified by roman numerals; (B) Superposition of the 3D structures of PIMT7 and PIMT8 with SpMTA. Proteins are in ribbon representation. The Cys residues are in stick representation; a Gln residue is also shown. The P. lividus proteins are in ivory, the $\alpha$-domain of SpMTA is shown in cyan and the $\beta$-domain is in violet. Superposition was created and rendered using Chimera package.

It should be noted that computational prediction of the metal binding sites in P. lividus as well as in S. purpuratus MTs suggests alternative thiolate clusters, composed by Cys encompassing residues from both the N- and C-domain. Thus, it could be hypothesised that a wide range of conformational states and metal interactions between domains could be supported.

\subsection{Phylogenetic Analysis of Deuterostome MTs}

In order to study metallothionein evolution in deuterostomes, annotated protein sequences were retrieved from databases. Moreover, when not already annotated, MT sequences were searched by similarity in transcriptome databases (Table 1). All available transcriptomes of Echinodermata species were considered, including Asteroidea (sea stars), Ophiuroidea (brittle stars), and Holothuroidea 
(sea cucumbers). Moreover, for understanding and gaining insight into the evolutionary trends of the MTs, phylogenetically interesting species belonging to non-vertebrate chordates as amphioxus and ascidians were considered [28-30]. Additionally, jawless vertebrates (agnates/Cyclostomata), representatives of an ancient vertebrate lineage, and relatively early diverging teleost fishes, like eels and cat fishes were selected. Also two well-studied fishes, the Japanese tiger puffer and the zebra-fish, and a human MT were chosen [31,32]. Unfortunately, no acorn worm (Hemichordata) nor sea lily (Crinoidea) MT sequences were found. The MSA between MTs from these different classes is shown in Figure 5. The alignment was also used to construct the phylogenetic tree shown in Figure 6. As an outgroup, an MT from the ciliate protozoa Tetrahymena pyriformis was selected. Tetrahymena MTs constitute an excellent example of an MT subfamily well studied in terms of molecular genetics and protein levels [33-35]. This subfamily is considerably divergent from the deuterostome paradigm, so it is unambiguously outside the clade of interest in this phylogenetic study. Nevertheless, they can be successfully aligned to sequences from the ingroup. Since the three MT isoforms identified in T. pyriformis are longer than deuterostome ones [36-38], we selected the shortest one (MT-2) as the outgroup.

The phylogenetic analysis of echinoderm MT sequences suggested that many events of gene duplication have occurred independently in different species. For each species the sequence divergence is very different, suggesting that gene duplication occurred after speciations and at different times. MTs of echinoderms exhibit high sequence heterogeneity, both among them and in relation to the vertebrate peptides, and PIMTs appear the most divergent. MTs of Eucidaris tribuloides, a representative cidaroid, branch apart from other sea urchin sequences, confirming cidaroids are the basal group within the class [39]. Echinarachnius parma, a representative clypeasteroida, results in the cidaroid sister branch.

Even though the inter-relationships of the classic deuterostome phyla appear to be resolved, the intra-relationships within each of the phyla have been troublesome and not completely concluded [40]. The analysis of the different classes of Echinodermata MTs suggests that ophiuroid MTs were more closely related to asteroid than to the echinozoan MTs and, in turn, to the holoturian MTs.

As already reported, the MT sequences of tunicates and amphioxus show a low identity with other deuterostome MTs, not being directly alignable to the isoforms of other classes $[28,30]$. Thus, Branchiostoma MTs appear in a separate tree branch with respect to the two tunicates and group with the echinoderm isoforms at a greater distance of the vertebrate counterparts. These MTs are the most similar to MTs of molluscs (data not shown). Sea squirt MTs are the shortest MTs so far identified in deuterostomes and are clearly separated from other Chordata and Echinodermata MTs. Finally, the MTs of lampreys, representatives of an ancient vertebrate lineage that diverged from our own $\sim 500 \mathrm{Myr}$, as expected, appear the nearest related to other vertebrata MTs.

In order to analyse also MT gene structure evolution, new BLAST searches in genomic databases were performed using MT mRNA sequences as queries (Table 1). Genomic sequences of already annotated $M T$ genes were also retrieved from databases. Novel annotated genes from selected genome draft sequences were compared to already known $M T$ genes. 
Table 1. Species, protein, transcript and gene sequence IDs collected for phylogenetical and gene structural analyses.

\begin{tabular}{|c|c|c|c|c|c|}
\hline Taxonomy & Species & Name & ID Protein/Reference & ID mRNA & ID Gene/Scaffold \# \\
\hline Echinoidea Echinoida & Paracentrotus lividus & PlMT4/8 & Ragusa et al., 2013 & & $\S$ \\
\hline Echinoidea Echinoida & Sterechinus neumayeri & SnMT & P55953 & & \\
\hline \multirow{3}{*}{ Echinoidea Echinoida } & \multirow{3}{*}{$\begin{array}{l}\text { Strongylocentrotus } \\
\text { purpuratus }\end{array}$} & SpMTA & P04734.2 & SPU_017989.3a & Scaffold1168 v3.1 \\
\hline & & SpMTB2 & Q27287 & SPU_017134.3c & Scaffold1906 v3.1 \\
\hline & & SpMTB1 & & SPU_001866.3a & Scaffold249 v3.1 \\
\hline \multirow{2}{*}{ Echinoidea Echinoida } & \multirow{2}{*}{ Heliocidaris tuberculata } & HtMT1 & $\delta$ & comp104953_c1_seq2 $\diamond$ & \\
\hline & & HtMT2 & 8 & comp104953_c1_seq1 $\diamond$ & \\
\hline \multirow{2}{*}{ Echinoidea Temnopleuroida } & \multirow{2}{*}{ Sphaerechinus granularis } & SgMTA & Q26497 & & \\
\hline & & SgMTB & Q26496 & & \\
\hline Echinoidea Temnopleuroida & Lytechinus pictus & LpMT1 & O02033 & & \\
\hline \multirow{2}{*}{ Echinoidea Arbacoida } & \multirow{2}{*}{ Arbacia lixula } & AlMT1 & \multirow[b]{2}{*}{$\S$} & c31462_g1_i3 II & \\
\hline & & AlMT2 & & c31386_g2_i2 II & \\
\hline $\begin{array}{c}\text { Echinoidea } \\
\text { Clypeasteroida }\end{array}$ & Echinarachnius parma & EpMT & $\S$ & GAVF01002251 & \\
\hline \multirow{3}{*}{ Echinoidea Cidaroida } & \multirow{3}{*}{ Eucidaris tribuloides } & EtMT1 & \multirow{3}{*}{$\S$} & JI315060 & § JZLH010301553 \\
\hline & & EtMT2 & & GAZP01041405 & \\
\hline & & EtMT3 & & JI295076 & \\
\hline Asteroidea & Asterias forbesi & AfMT & $\S$ & GAUS01062044.1 & \\
\hline Asteroidea & Asterias rubens & ArMT & $\S$ & GAUU01048766.1 & \\
\hline Asteroidea & Asterias amurensis & AamMT & $\S$ & GAVL01015559.1 & \\
\hline Asteroidea & Leptasterias sp. AR-2014 & LsMT & $\S$ & GAVC01041863 & \\
\hline \multirow{3}{*}{ Ophiuroidea } & \multirow{3}{*}{ Ophiocoma echinata } & OeMT1 & \multirow{3}{*}{$\S$} & GAUQ01108229 & \\
\hline & & OeMT2 & & GAUQ01027563 & \\
\hline & & OeMT3 & & GAUQ01073893 & \\
\hline Holothuroidea Aspidochirotida & Apostichopus japonicus & AjMT & $\S$ & GH551565 & $\S$ MODV01037111 +MODV01043468 \\
\hline Holothuroidea Aspidochirotida & Parasthicopus parvimensis & РpMT & $\S$ & Locus_1_Transcript_31588/53328 & $\begin{array}{c}\text { § Scaffold4005 KN886207.1 + } \\
\text { Scaffold3285 KN885487.1 }\end{array}$ \\
\hline Holothuroidea Aspidochirotida & Parastichopus californicus & PcMT1 & $\S$ & GAVO01014408.1 & \\
\hline Holothuroidea Dendrochirotida & Sclerodactyla briareus & SbMT & $\S$ & GAUT01018048.1 & \\
\hline
\end{tabular}


Table 1. Cont.

\begin{tabular}{|c|c|c|c|c|c|}
\hline Taxonomy & Species & Name & ID Protein/Reference & ID mRNA & ID Gene/Scaffold \# \\
\hline Crinoidea & & - & & & \\
\hline Hemichordata & & - & & & \\
\hline Urochordata Enterogona & Ciona intestinalis & CiMT1 & ACN32211.2 Franchi et al., 2010 & BW491384 FJ217357 & Scaffold 186 (JGI database) \\
\hline Urochordata Enterogona & Ascidia sydneiensis samea & AsMT & Yamaguchi et al., 2004 & Asy-sig-715 and Asy-sig-997 & \\
\hline Urochordata Stolidobranchia & Herdmania curvata & $\begin{array}{l}\text { HcMTA } \\
\text { HcMTb }\end{array}$ & $\S$ & $\begin{array}{c}\text { AY314949 } \\
\text { AY314939.1 }\end{array}$ & \\
\hline Urochordata Stolidobranchia & Herdmania momus & HmMT & $\S$ & EL733027.1 & \\
\hline Cephalochordata Amphioxiformes & Branchiostoma floridae & $\begin{array}{c}\text { BfMT1 } \\
\text { BfMT2_S }\end{array}$ & Guirola et al., 2012 & $\begin{array}{l}\text { BW764364 } \\
\text { FE561990.1 }\end{array}$ & Guirola et al., 2012 \\
\hline Cephalochordata Amphioxiformes & Branchiostoma belcheri & BbMT20 & XP_019631158.1 & XM_019775599.1 & NW_017803933 (AYSS01018500) \\
\hline Craniata Cyclostomata & Lethenteron camtschaticum & LcMT & $\S$ & DC612982.1 & $\begin{array}{c}\text { § APJL01076593 + APJL01076594 + } \\
\text { APJL01076595 }\end{array}$ \\
\hline Craniata Cyclostomata & Petromyzon marinus & PmMT & $\S$ & CO548937.1 & \\
\hline Craniata Gnathostomata Elopomorpha & Anguilla anguilla & AaMT & ABF50549.1 & DQ493910.1 & § AZBK01727549 \\
\hline Craniata Gnathostomata Otomorpha & Ictalurus punctatus & IpMT & O93571 & $\begin{array}{c}\text { NM_001200077.1 or AF087935 } \\
\text { and JT349175.1 }\end{array}$ & NC_030419 \\
\hline Craniata Gnathostomata Otomorpha & Clarias macrocephalus & CmMT & AGC79138.1 & JX312865.1 & \\
\hline \multirow[t]{2}{*}{ Craniata Gnathostomata Otomorpha } & \multirow[t]{2}{*}{ Danio rerio } & $\begin{array}{l}\text { DrMTBl } \\
\text { (like) }\end{array}$ & $\begin{array}{l}\text { ENSDARP00000131449 } \\
\text { (CAA65933.1) }\end{array}$ & ENSDART00000170342 & ENSDARG00000102051 \\
\hline & & DrMT2 & $\begin{array}{l}\text { ENSDARP00000061006 } \\
\text { (AAH49475.1) }\end{array}$ & ENSDART00000061007 & ENSDARG00000041623 \\
\hline $\begin{array}{l}\text { Craniata Gnathostomata } \\
\text { Euteleosteo-morpha }\end{array}$ & Takifugu rubripes & TrMT2 & ENSTRUP00000022394 & ENSTRUT00000022487 & ENSTRUG00000008907.1 \\
\hline Craniata Gnathostomata Primates & Homo sapiens & HsMT1A & NP_005937.2 & NM_005946 & Gene ID: 4489 \\
\hline
\end{tabular}

Scaffold \#: Scaffold number. § Sequences identified in this work. $\diamond$ Heliocidaris T_Trinity database. II Available in Echinobase. 

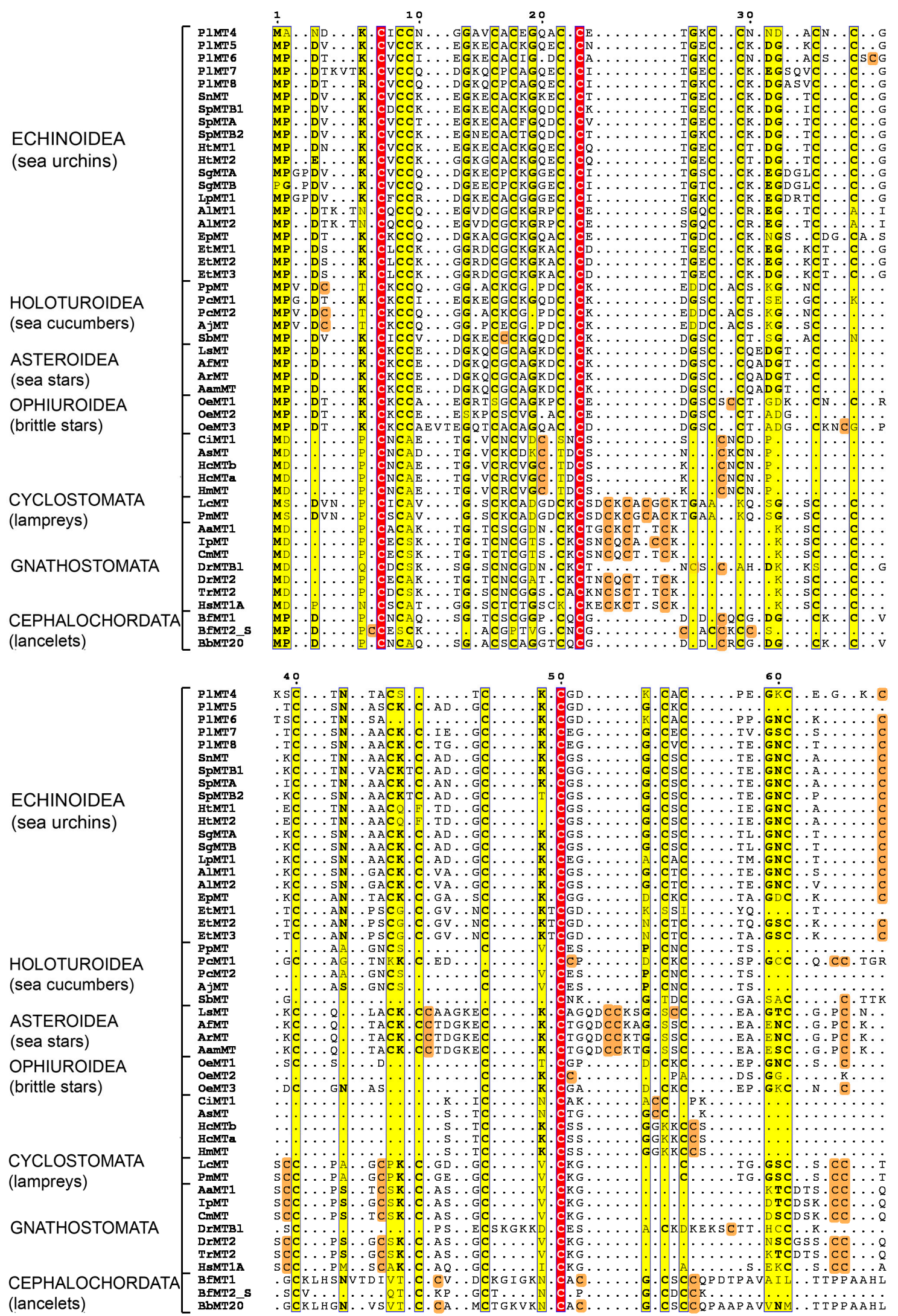

Figure 5. MSA of MT protein sequences. Conservation score higher than 0.5 is highlighted in yellow. Unaligned cysteines are in orange. Cysteines aligned in all sequences are highlighted in red. Dots denote gaps. Species acronyms, taxonomy and sequence IDs are indicated in Table 1. 


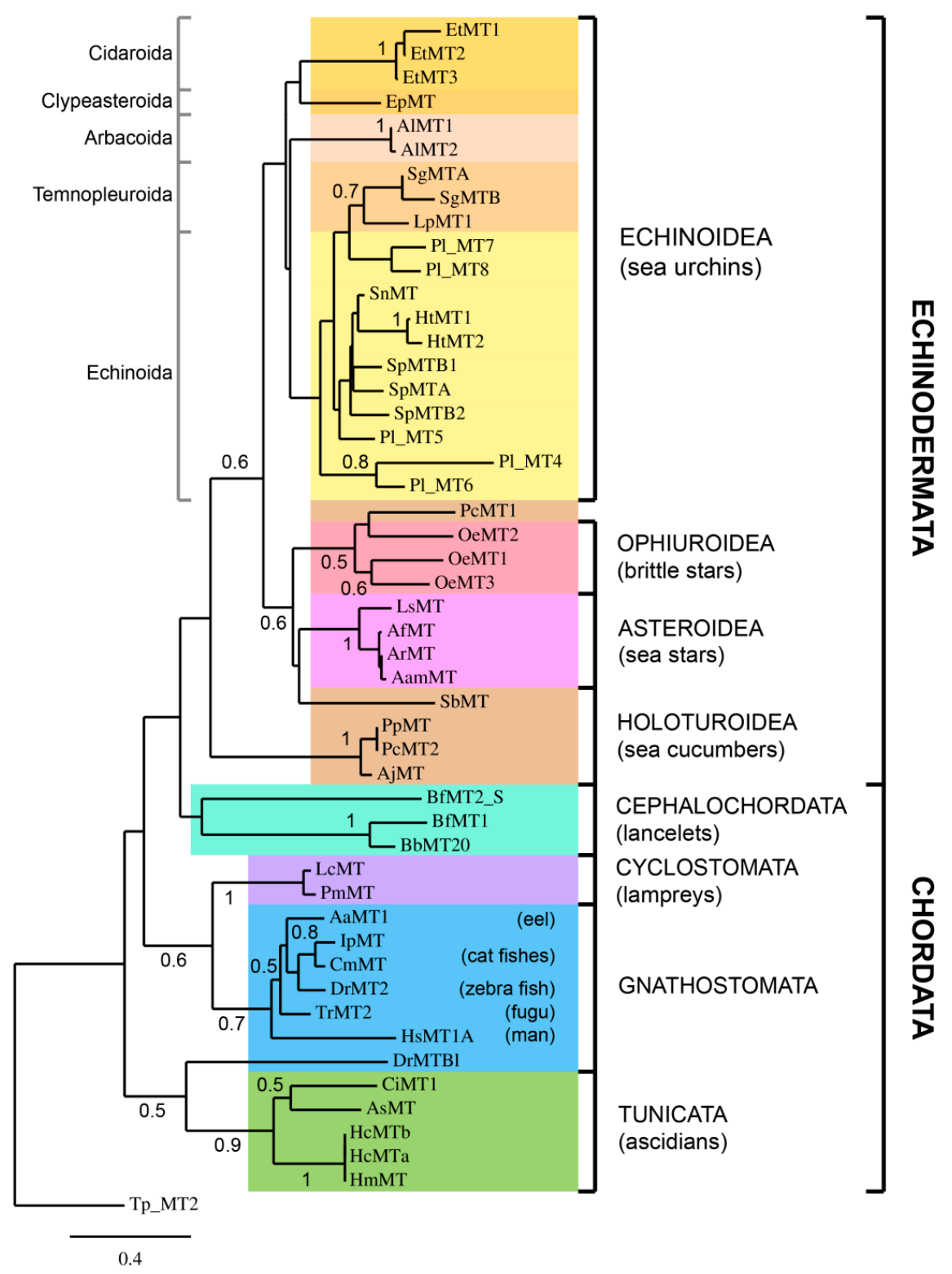

Figure 6. Amino acid sequence-based neighbour-joining tree. Species acronyms and sequence IDs are indicated in Table 1. The values at nodes indicate bootstrap support greater than $50 \%$. Tetrahymena pyriformis was used as outgroup to root the tree. Branch lengths are drawn to a scale of amino acid substitutions per site.

For the first time, $M T$ genes of the slate pencil urchin of the Cidaroida order (E. tribuloides), two sea cucumbers (Apostichopus japonicus and Parasthicopus parvimensis), a lamprey (Lethenteron camtschaticum) and an eel (Anguilla anguilla) were characterized. Gene structures are depicted in Figure 7 and show clearly the high variability of intron lengths, the longest being the Cidaroida E. tribuloides gene and the shortest the fish genes. All the introns that interrupt the coding regions of the selected genes are in phase- 1 and all the coding regions with the exclusion of the ascidian one [28] are interrupted by two introns. Interestingly, the lamprey gene contains also the intron in the $3^{\prime}$ UTR like echinoderm and ascidian ones. As already reported, lancelet (Branchiostoma floridae) gene structures are in some way unique, indeed BfMT1 lacks the intron in the $3^{\prime}$ UTR and the BfMT2 first intron is located at only 4 codons from the ATG [30]. Thus, also gene structures reflect divergence in coding sequences. 


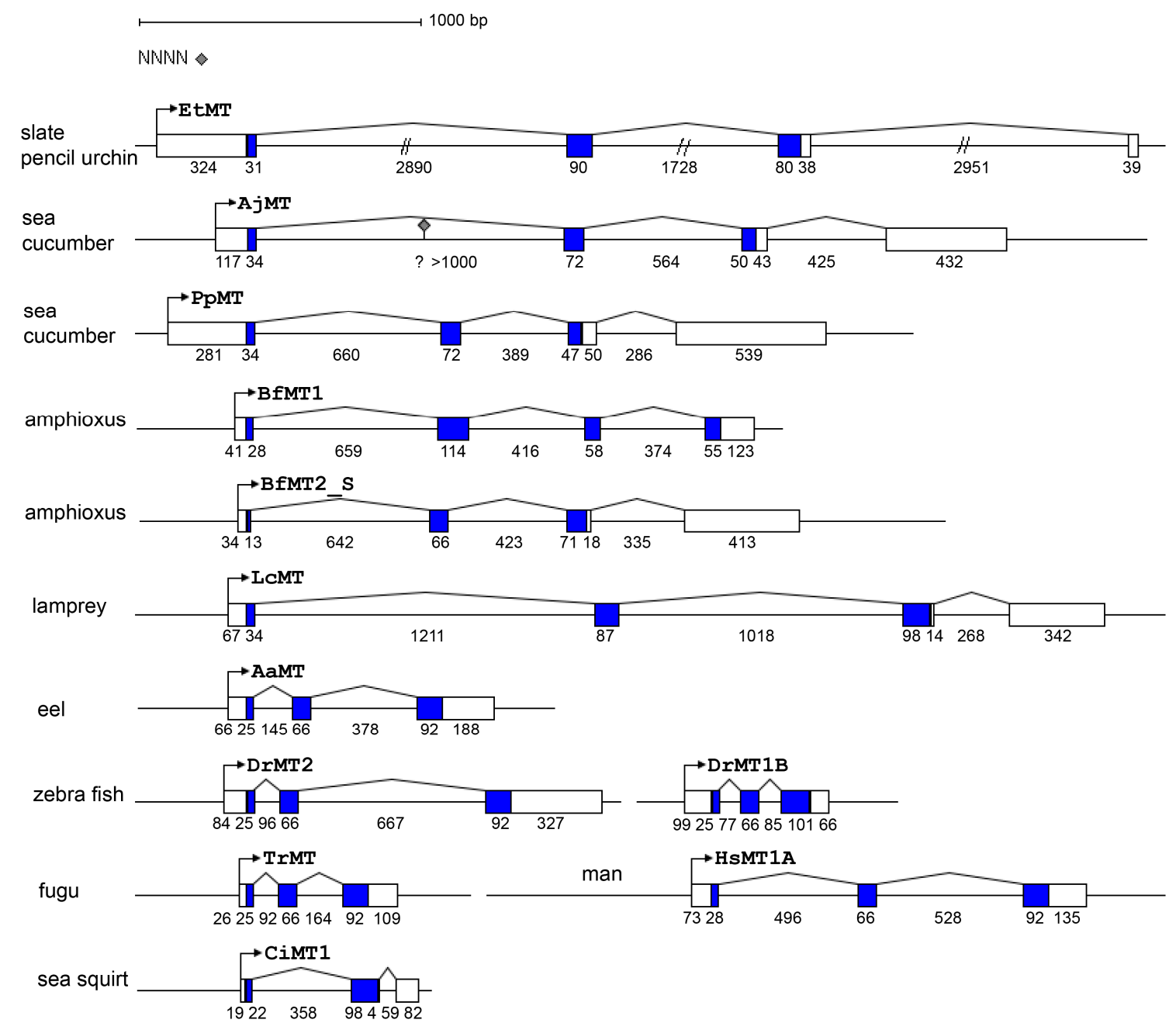

Figure 7. MT gene structures of echinoderms and chordates (drawn to scale). The bent arrows indicate the putative TSSs. Numbers under schemes indicate base pair numbers of exons and introns; boxes represent exons: white boxes indicate untranslated regions, and coding regions are coloured. The grey diamond indicates one $\mathrm{N}$ stretch in the AjMT intron.

\subsection{Expression of P. lividus MT Family Genes during Development and after Metal Treatments}

\subsubsection{Physiological Expression during Embryogenesis}

As already reported [25], embryos growing in normal conditions at the gastrula stage express MT7 and MT8 transcripts at high levels. Conversely, MT4, MT5 and MT6 are expressed at low levels. In order to study metallothionein expression throughout $P$. lividus embryo development, reverse transcription and quantitative (real time) PCR (RT-qPCR) experiments were performed. During development under normal conditions, MT4, MT5 and MT6 are expressed at very low levels, however levels rise significantly between 16 and $20 \mathrm{~h}$ and then decrease at the later stages $(31 \mathrm{~h})$, showing a second intensification peak at $36 \mathrm{~h}$ (mainly MT5 and MT6). The MT8 expression profile during development is similar, even if its average level is much higher. Conversely, MT7 (the most expressed MT) increases not only during the beginning of gastrulation but also at the later stages, reaching a peak at the pluteus stage (Figure 8). 

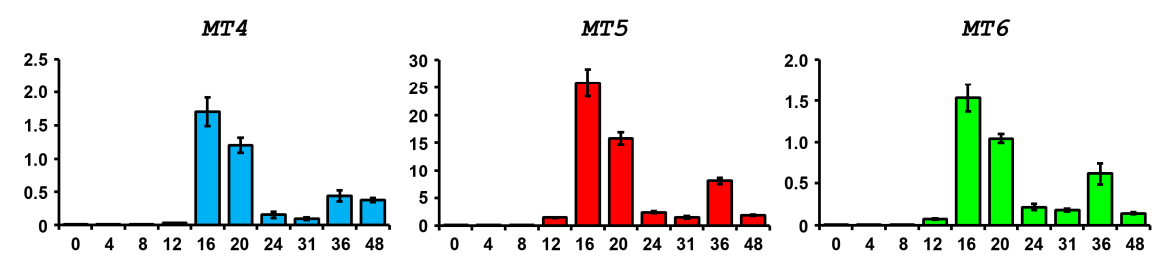

$M T 7$

MT8

MTS
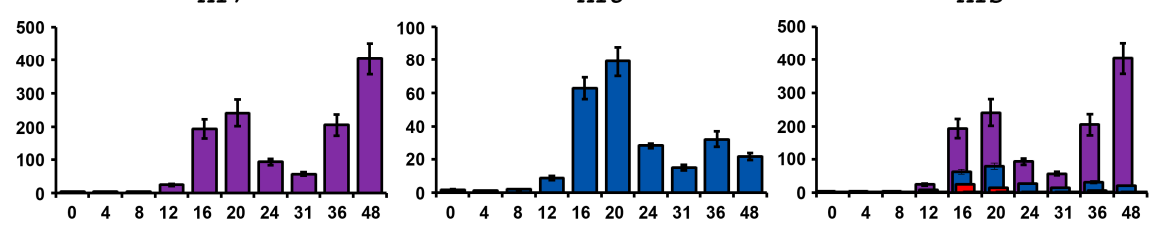

Figure 8. MT expression during normal development. RT-qPCR results are shown in arbitrary units (AU) with respect to 18S RNA. The last panel (MTs) show the superposition of the other profiles, in order to display MT relative expression.

\subsubsection{Expression after Metal Exposure}

Metals, such as copper, zinc, lead, mercury and nickel, can all act as poisons or teratogens, causing deformities or deaths in many organisms exposed to them. It is well known that sea urchins are particularly susceptible to environmental conditions and respond readily [41,42]. It is widely accepted that MTs are involved in many functional roles, ranging from toxic metal protection and physiological homeostasis, to free-radical scavenging or oxidative stress protection and antiapoptotic defences.

In order to extend the knowledge on the functional role of P. lividus MTs, we studied their mRNA expression in response to metal exposure. Embryos were treated during development with different metals: zinc $(\mathrm{Zn})$ and copper $(\mathrm{Cu})$, two essential metals, and a metal with intermediate characteristics, nickel (Ni). Moreover, since we already studied PlMT expression in response to cadmium exposure [25], we chose lead $(\mathrm{Pb})$ as a nonessential metal with recognized toxicity. Embryos were continuously treated with metal concentrations ranging from $10^{-8}$ to $10^{-4} \mathrm{M}$, except the $\mathrm{Cu}$ treatment, that ranged from $10^{-8}$ to $10^{-5} \mathrm{M}$, because embryos exposed to $10^{-4} \mathrm{M} \mathrm{CuSO}_{4}$ did not survive. It is in fact known that copper is the most toxic metal to developing embryos and larvae of sea urchin $[43,44]$.

The development of treated and untreated embryos was observed under microscope until $48 \mathrm{~h}$ post fertilization. In order to study the response caused by metals, RNAs were extracted from embryos at $24 \mathrm{~h}$ of development, corresponding to gastrula stage in normal conditions, when all MT transcripts are expressed at relatively low levels. RNA were used in RT-qPCR experiments for testing $M T$ transcript relative quantities (Figures 9 and 10).
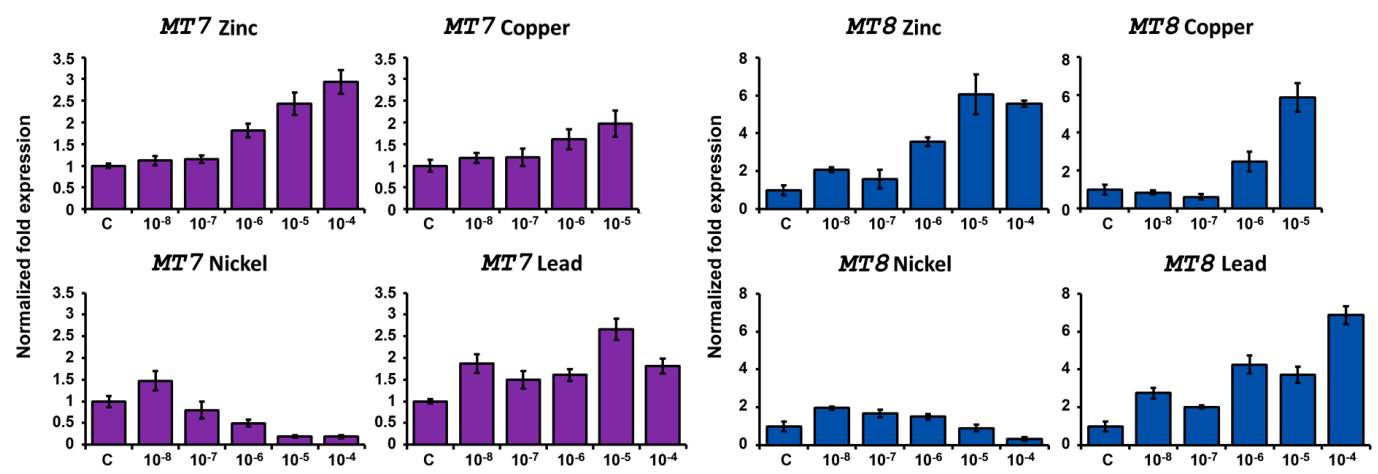

Figure 9. Expression of constitutive MTs after metal exposure. RT-qPCR results performed on RNA extracted from $24 \mathrm{~h}$ embryos treated with zinc, copper, nickel or lead. C: controls grown in millipore-filtered seawater (MFSW). Metal treatments were performed with concentrations ranging from $10^{-8}$ to $10^{-4} \mathrm{M}$. Copper treatments ranged from $10^{-8}$ to $10^{-5} \mathrm{M}$. 

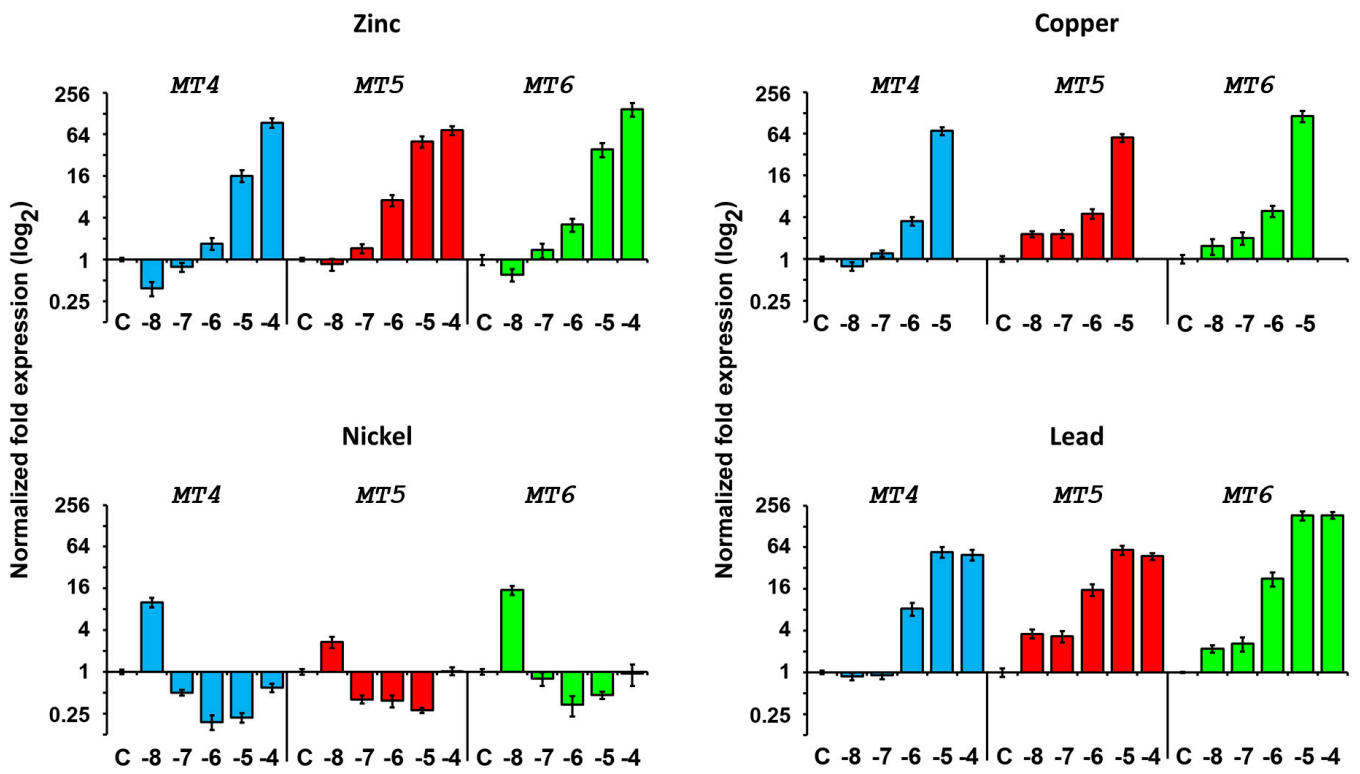

Figure 10. Expression of induced MTs after metal exposure. RT-qPCR results performed on RNA extracted from $24 \mathrm{~h}$ embryos treated with zinc, copper, nickel or lead. C: controls (MFSW). Metal treatments were performed with concentrations ranging from $10^{-8}(-8)$ to $10^{-4} \mathrm{M}(-4)$. Copper treatments ranged from $10^{-8}(-8)$ to $10^{-5} \mathrm{M}(-5)$. These graphics are in $\log _{2}$ scale.

\section{Zinc Treatment}

According to previous studies, low levels of zinc had no effect on the development of the sea urchin embryos, however higher concentrations caused abnormal development, animalizing the embryos $[45,46]$.

RT-qPCR results showed that embryo exposure up to $10^{-7} \mathrm{M}$ Zn does not grossly affect MT7 levels. Conversely, higher concentrations cause a progressive increase in level of this transcript. It is worth noting that MT7 levels are high also in embryos developed in normal conditions and that the 3-fold upregulation caused by zinc is the highest observed. Instead, MT8 expression is affected also at the lower $\mathrm{Zn}$ concentration tested, rising until $10^{-5} \mathrm{M}$ and then reaching a plateau (6-fold with respect to controls). The low $\mathrm{Zn}$ concentration $\left(10^{-8} \mathrm{M}\right)$ causes a decrease of induced MTs (especially MT4), conversely, higher concentrations stimulate gene expression progressively $(>100 \times)$.

\section{Copper Treatment}

$\mathrm{Cu}$ has been shown to cause multiple deformities. Most of these abnormalities occurred at the gastrulation stage of development [47]. At low concentrations, radialized plutei larvae were observed. Developmental effects on the skeleton, consisting of an underdeveloped skeleton with no spicule formation or multiple triradiate spicules and elongated spicules were observed [48]. Despite these abnormalities, MT levels are affected only at relatively high concentrations. Indeed, all MTs except MT5 increase in their levels between $10^{-7}$ and $10^{-6} \mathrm{M}$. MT5 responds first, rising readily at the lowest tested concentration $\left(10^{-8} \mathrm{M}\right)$.

\section{Nickel Treatment}

$\mathrm{Ni}$ ventralizes the ectoderm; as a consequence, the arrangement of primary mesenchyme cells (PMCs) in the blastocoel is altered and the number of spicule rudiments is increased [49,50]. All MTs increase at the lower metal concentration and decrease at all other tested concentrations. It is worth noting that Ni influences very little MT transcript levels with respect to other metals. 


\section{Lead Treatment}

$\mathrm{Pb}$ is considered less toxic for P. lividus embryos than $\mathrm{Cu}[43,51]$, on the other hand its bioaccumulation proceeds faster than $\mathrm{Cu}$ [52]. When embryos were raised continuously in $\mathrm{Pb}$, both the patterning of the PMC ring and the expression of MTs were altered, having a pattern very similar to zinc response. However, maximal levels of transcripts were reached with the $10^{-5} \mathrm{M} \mathrm{Pb}$ treatment for all MTs except for MT8. MT8 indeed peaked at $10^{-4} \mathrm{M} \mathrm{Pb}$.

\subsection{Spatial Patterns of MT Gene Expression}

In order to complete the MT expression overview and to shed some light on MT function/utilization during normal development and under metal exposure, we performed whole-mount in situ hybridization experiments (WMISH). Because the effects of metal treatments appear clearly visible during gastrulation, developmental stages corresponding to gastrula and pluteus were used in WMISH to define the MT expression in the different embryo tissues and cell types.

As shown in Figure 11A, the embryos grown in uncontaminated seawater display robust MT7 expression, indeed staining times of only 15 min were sufficient to detect the transcript. At the gastrula stage, MT7 is localized principally in the endomesoderm, in the vegetal pole. Progressively, it becomes heavily expressed in the endoderm during archenteron specialization in midgut and hindgut and then in stomach and intestine at the pluteus stage. Besides this localization at a very high level, MT7 is also expressed in all other tissues, as shown after $1 \mathrm{~h}$ of staining (Figure $11 \mathrm{~A}(\mathrm{~g}, \mathrm{~h})$ ).

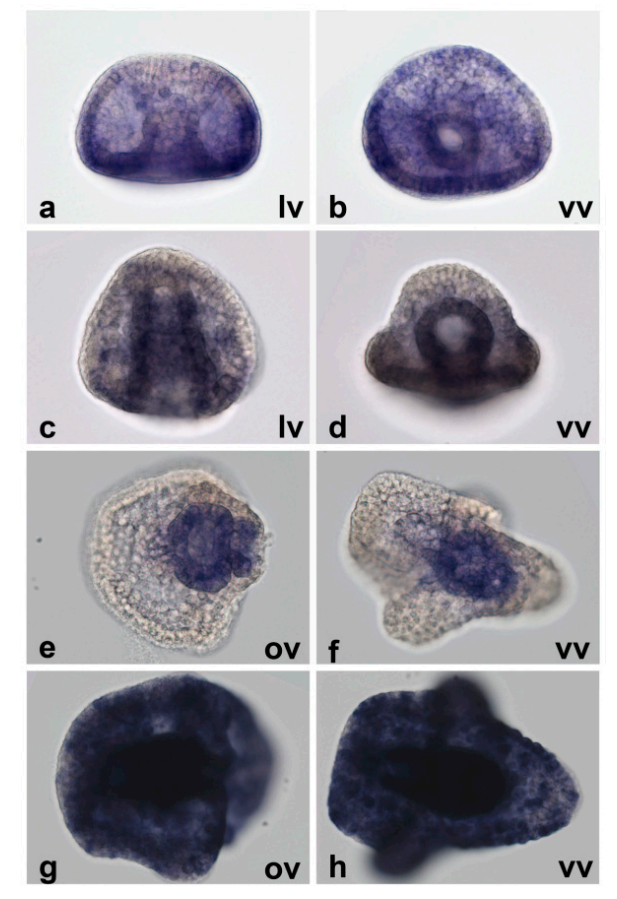

(A)

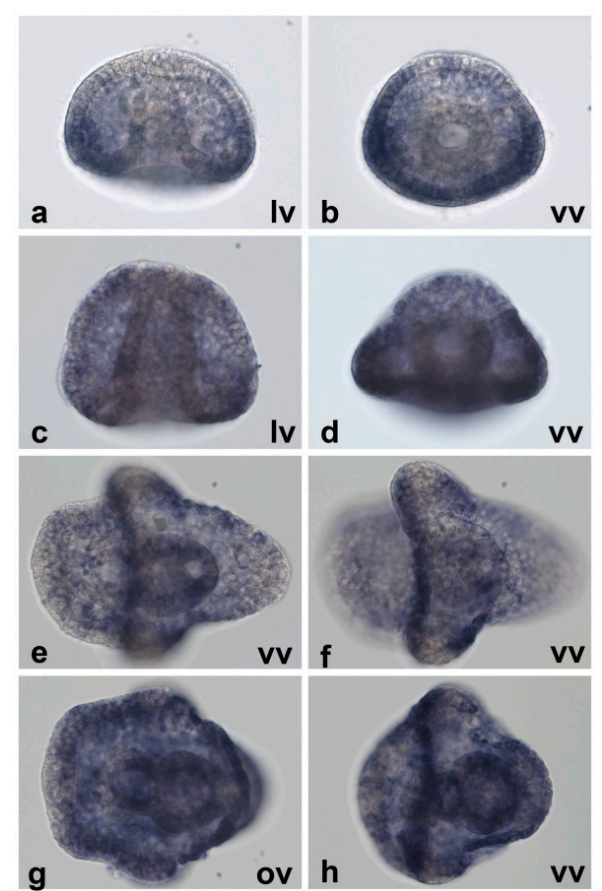

(B)

Figure 11. Localization of constitutive MTs during normal development. Whole-mount in situ hybridization experiments (WMISH) results, $1 \mathrm{~h}$ of staining. (A) MT7; (B) MT8: (a,b) gastrula stage (24 h); (c,d) prisma stage (31 h); (e-h) pluteus stage (48 h); (e,f) in the (A) panel, visualization after $15 \mathrm{~min}$ of staining; (e,f) in the (B) panel, different focuses of the same embryo are shown. $40 \times$ magnification. lv: lateral view; vv: ventral view; ov: oral view.

In contrast, at the gastrula stage MT8 appears localized in the oral ectoderm and in the ventral region of the ciliary band. It is not expressed in the archenteron, not even at the later stages of development. At the pluteus stage, it is mainly localized in a narrow strip of cells between the anal 
arms of the larva (the boundary between oral and aboral ectoderm) and lightly in the oral ectoderm (Figure 11B).

The levels of inducible MTs are very low in control embryos, thus they are usually undetectable by WMISH. At the pluteus stage (that corresponds to a peak of expression) MT5 does not appear (see Figure 12A(a,b)); conversely, MT6 is detectable in couples of cells at the tips of the elongating anterolateral and postoral skeletal rods, while no expression is visible in cells of the apex (Figure 12B,C). MT4 is not detected at any stage, presumably because its messages, that are expressed at very low levels, are widely dispersed (data not shown).

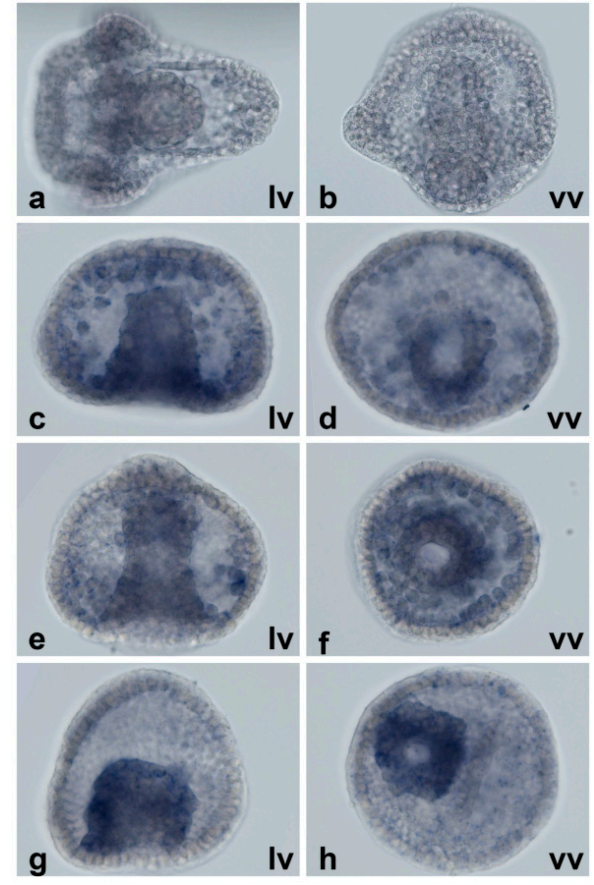

(A)

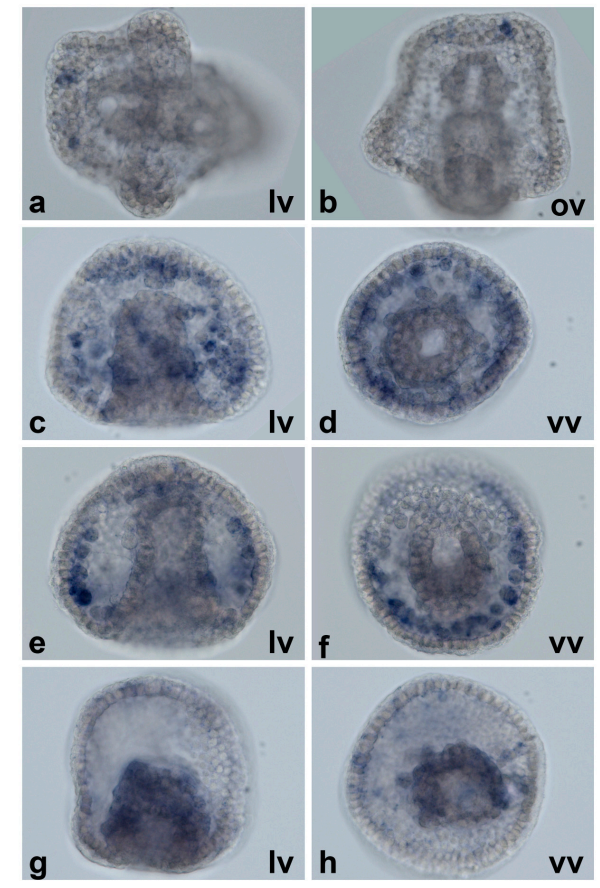

(B)

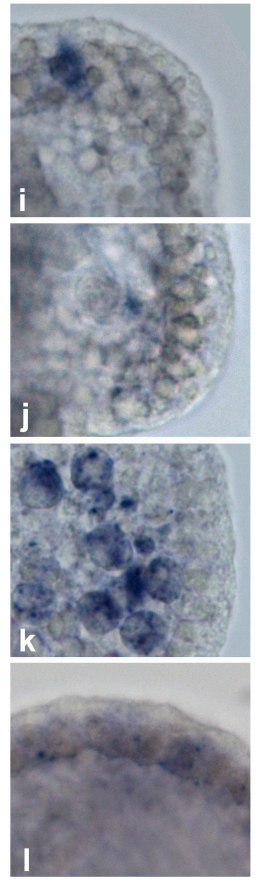

(C)

Figure 12. Localization of induced MTs at $48 \mathrm{~h}$ of normal development and after metal exposure. WMISH results. (A) MT5; (B) MT6; (C) MT6 details: (a,b) untreated embryos, pluteus stage (48 h) after $3 \mathrm{~h}$ of staining; (c,d) $10^{-7} \mathrm{M} \mathrm{CdCl}_{2}$ prisma stage (31 h); (e) and (f) $10^{-6} \mathrm{M} \mathrm{CuSO}_{4}$ prisma stage $(31 \mathrm{~h}) ;(\mathbf{g}, \mathbf{h}) 10^{-7} \mathrm{M} \mathrm{ZnCl}_{2}$ prisma stage $(31 \mathrm{~h})$; (C) enlargements of the $(\mathbf{B})$ panel: $(\mathbf{i}, \mathbf{j})$ enlargement of (b), untreated embryos, pluteus stage (48 h); (k) $10^{-7} \mathrm{M} \mathrm{CdCl}_{2}$ prisma stage (31 h) enlargement of (e) (different focus plan); (1) $10^{-7} \mathrm{M} \mathrm{ZnCl}_{2}$ prisma stage (31 h) enlargement of (g) (different focus plan). $40 \times$ magnification. lv: lateral view; vv: ventral view; ov: oral view.

Taking into account the localization of MTs transcripts in control embryos, we decided to perform WMISH experiments on embryos exposed to metals $\left(10^{-7} \mathrm{M} \mathrm{CdCl}_{2}, 10^{-7} \mathrm{M} \mathrm{ZnCl}_{2}\right.$ or $\left.10^{-6} \mathrm{M} \mathrm{CuSO}_{4}\right)$ that disrupt development, affecting oral/aboral axis formation. Consequently, PMCs are not directed to their correct arrangement in a posterior ring around the blastopore with ventrolateral clusters, thus impairing skeletogenesis [49,50]. In cadmium and copper treated embryos, after their ingression into the blastocoel, PMCs migrate into a ring pattern within the blastocoel. In Zn-treated embryos, ectoderm territory is expanded and mesenchyme cells do not detach from the endoderm and take up position covering the entire abnormal archenteron.

WMISH showed that in embryos treated with each metal, MT7 is overexpressed throughout the embryo (Figure 13A). MT8 loses its localization in the oral ectoderm and in the ventral ciliary band, and it becomes uniformly distributed in the unspecialized ectoderm (Figure 13B). In any case, it is never detectable in the endoderm. 


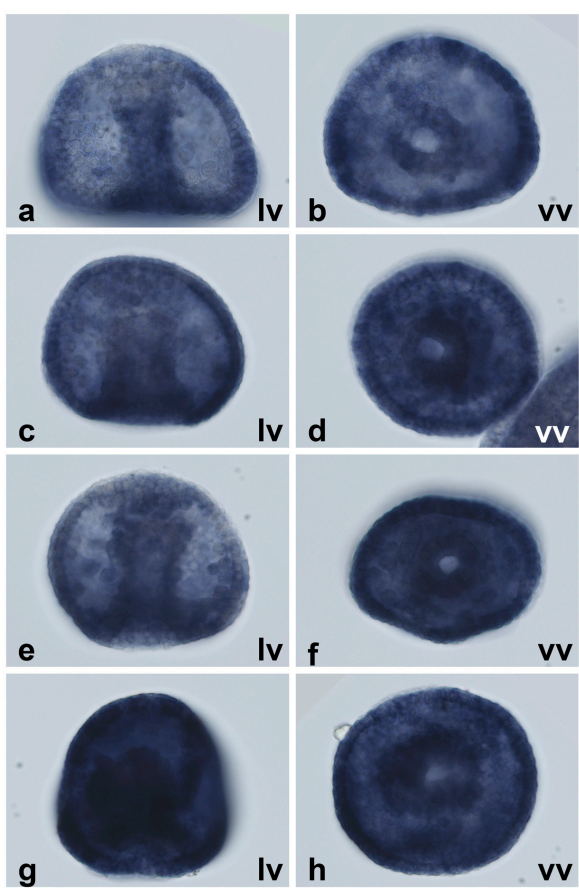

(A)

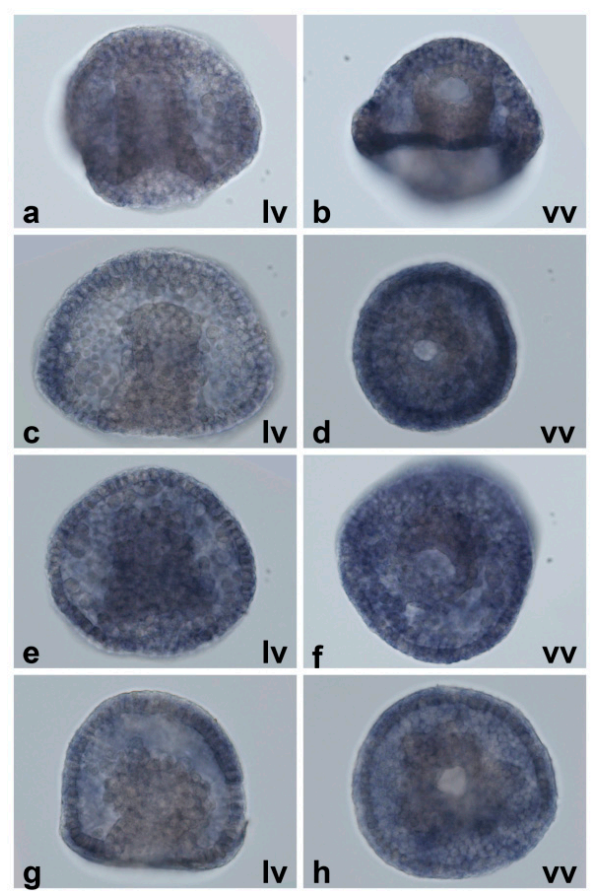

(B)

Figure 13. Localization of constitutive MTs after metal exposure. WMISH results at $31 \mathrm{~h}$ (prisma stage in the controls). (A) MT7; (B) MT8; (a,b) untreated embryos (controls); (c,d) $10^{-7} \mathrm{M} \mathrm{CdCl}_{2}$; (e,f) $10^{-6} \mathrm{M} \mathrm{CuSO}_{4}$; (g,h) $10^{-7} \mathrm{M} \mathrm{ZnCl}_{2}$. $15 \mathrm{~min}$ of staining. $40 \times$ magnification. lv: lateral view; vv: ventral view.

Differently from constitutive isoforms, in the embryos treated with metals MT5 and MT6 are expressed in the mesenchyme cells, no matter where they are arranged in the blastocoel (Figure 12). MT5 is also slightly expressed in the hindgut. Interestingly, at higher magnification it appears that the hybridization signals are not homogeneously distributed within the cells (Figure 12C(k)). Additionally, in the blastocoel surface of some ectodermal cells a few punctiform signals appear (Figure 12C(l)).

\section{Discussion}

In P. lividus embryos, the first MTs were described by Scudiero et al. [53] and the first cDNA was obtained in the Matranga lab, here referred to as Pl-MT1 [54]. In a previous work we isolated five cDNAs, one of them (MT8) with a sequence very similar to Pl-MT1 [25].

Here, we studied the MT multigene family of the Mediterranean sea urchin species of Parechinidae and compared it to that of other echinoderms and early chordates. The P. lividus genome harbours at least seven expressed metallothionein genes that we characterized. By a transcriptome-wide survey, for the first time, we identified expressed RNA sequences that encode previously uncharacterized MTs. Moreover, we described the MT gene structures of a slate pencil urchin, two sea cucumbers, a lamprey and an eel. All the echinoderm MT genes share the same intron-exon organization. Interestingly, the lamprey gene also displays the same structure, indicating that the last common ancestor of vertebrates and echinoderms could have the intron in the $3^{\prime}$ UTR and that this intron would have been lost after the branching of the jawless fishes (Cyclostomata) and the jawed vertebrates (Gnathostomata).

As the slate pencil urchin E. tribuloides, a member of the basal echinoid order Cidaroida, shows the longest $M T$ gene here described (and the fishes the shortest ones), we can infer that $M T$ gene structure was characterised by a decrease in intron length during evolution. It is known that large introns can contribute to proteome diversity by facilitating alternative splicing [55]; on the other hand, during evolution eukaryotes seem to have undergone extensive intron loss, favouring high expression levels. It has also been described that genes that are rapidly regulated during stress contain significantly 
reduced intron numbers and length [56]. Since $M T$ genes are highly expressed and/or rapidly activated after stimuli, these theses could fit to the observations we made on the MT intron evolution.

Transcriptome searches revealed up to three paralogs in echinoderm species examined and one or two in chordates. It is worth noting that this analysis (in transcriptomes of organisms grown in normal conditions) does not allow finding other possible MTs not constitutively expressed and induced by a stimulus. It could be interesting to know the complete MT families of other Echinodermata, in order to infer their possible orthology. Incidentally, the fact that the genes coding for metallothioneins are not ordinarily annotated by gene-finding programs is not surprising, because the coding regions are not only very small but also interrupted by large introns. In any case, the identified "constitutive" SpMTs are very similar among them, as P. lividus constitutive isoforms; conversely, P. lividus-induced MTs diverge particularly in the C-terminal domain. Since SpMTA 3D structure is known, by homology modelling we modelled the PIMT structures, revealing that, as expected, MT7 and MT8 show a 3D structure similar to SpMTA. Differently, MT4 and MT5 appear to be more compact than MT6, 7 and 8 with less distinguishable $\alpha$ - and $\beta$-domains.

The phylogenetic analysis of protein sequences suggests that ophiuroids were more closely related to asteroids than to the echinozoans (the asterozoan hypothesis reviewed in [57]). Moreover, our results confirm the recent estimate of chordate intra-relationships: that chordates are monophyletic and that vertebrates share a last common ancestor with urochordates to the exclusion of cephalochordates [30,40]. Indeed, as shown before [30], phylogenetic studies places amphioxus MTs in the same echinoderm branch.

PIMTs show not only a high degree of evolutionary sequence and structure differentiation but also a high degree of functional differentiation: PIMT genes are differently expressed, both quantitatively and spatially, and respond distinctively to metal-dependent transcriptional activation. Indeed, MT7 and MT8 are expressed under physiological conditions at different levels and in different tissues (see also [58]), besides they respond relatively little and differently from each other to metal overload.

Conversely, MT4, 5 and 6 are expressed at basal levels during normal development and their expression bursts under metal exposure. Differences can also be found between these induced isoforms; indeed, MT4 is probably widespread in the embryo, while MT5 and MT6 are expressed in the mesodermal cells. In particular, MT6 is highly expressed under normal conditions in a very low cell numbers, at least at the pluteus stage. Its localization resembles that of Lvmsp130 [59] in cells at the tip of the skeletal rods, even though we could not observe expressing cells in the scheitel. Probably, as with Lvmsp130, the reduction in MT6 mRNA levels at later stages could be due to a minor number of expressing cells (only a subset of the PMCs).

Interestingly, even taking into account their difference in quantity, the MTs grossly exhibit the same level variations during development. This could be related to the fluctuation in the overall transcription during embryogenesis; however, the induced MTs peak at $16 \mathrm{~h}$ after fertilization, before the other MTs and just when PMC ingression occurs. Thus, it is reasonable to suppose a role for these MTs in PMC differentiation and/or activity.

It is known that both $\mathrm{Pb}$ and $\mathrm{Zn}$ render their toxic effects through disruption of $\mathrm{Ca}$ homeostasis [60,61], impairing calcium accumulation which is necessary for spicule deposition. Indeed, the sea urchin skeleton is composed of the calcium carbonate mineral calcite and numerous associated proteins [62]. Thus, treatment with metals impairs skeletogenesis, although in different manners, directly affecting the biomineralization process and/or disrupting the oral aboral axis and then PMC localization $[49,50]$.

Unexpectedly, MT5 and MT6 WMISH signals do not seem uniform in the PMCs. This could be a technical artefact; alternatively, these transcripts could be accumulated in vesicles. Indeed, Beniash et al. [63] showed that the PMCs contain electron-dense granules (named calcein puncta) which correspond to calcium-rich vesicles that contain nanospheres of amorphous calcium carbonate which then partially transforms into calcite during spicule mineralization. The calcein puncta are 
distributed widely all over the embryo, not only in the primary mesenchyme cells but also in the surface of the epithelial cells [64].

All this, and also the puncta observed in the surface of the epithelial cells, suggests that MT5 and MT6 could be accumulated in the calcein puncta. Thus, MT induction and mRNA storage just in PMC puncta after metal exposure corroborate the hypothesis of a protective role during calcium deposition in skeletogenesis.

Although it is not possible to infer orthology from MT sequences of sea urchins, it should be remembered that $S$. purpuratus $M T$ s also exhibit different spatial, temporal and quantitative patterns of expression $[21,65,66]$. Hence, SpMTA is transcribed in ectodermal tissues, such as PlMT8, while SpMTB is expressed in both the ectodermal and endodermal structures, such as PIMT7. However, quantitative patterns are inverted. Indeed, under physiological conditions SpMTA mRNA levels reach up to 10 times those of $S P M T B$, and PlMT8 levels are five times lower than PIMT7. Moreover, under metal overload, SPMTB and PIMT7 expression is further induced, so that SPMTB and PlMT7 achieve levels similar to those of PIMT8 and SPMTA, respectively.

In summary, P. lividus MTs show a high polymorphism both in sequence/structure and expression pattern. In the light of our findings it seems reasonable to consider MT7 and MT8 as the major variants associated with physiological functions, playing their major roles in metal homeostasis and redox activity in ecto-, meso- and endo-dermal tissues. On the other hand, a heavy metal detoxification role can be attributed to MT4, 5, and 6, particularly important in mesenchyme cells for the skeletogenic pathway. However, since differences not only between the two classes occur, each isoform would correspond to a more definite physiological function. In fact, it was also recently demonstrated that induced PlMTs are regulated in dissimilar manners by oxylipins, the polyunsaturated aldehydes produced by diatoms $[67,68]$. Also, manganese exposure caused a slight up-regulation of MT5 and MT8, and a down-regulation of MT6 expression at the pluteus stage [69,70].

Thus, it will be interesting to obtain information on the transcriptional mechanisms that control basal and induced MT gene expression in sea urchin embryogenesis, in physiological and stress conditions.

\section{Materials and Methods}

\subsection{Database Analysis, Cloning and Sequence Analysis of MT Genes}

P. lividus MT cDNA sequences previously identified [25] were used as queries in a genome-wide basic local alignment search tool (BLAST) [71] screening of genomic scaffolds in the P. lividus (genomic draft) database (v2.0, available at http://octopus.obs-vlfr.fr/index.php). These partial genomic sequences were essential to design oligonucleotides required for amplification (Table 2). When genomic sequence was not available in the database, the cDNA sequence was used as primer template.

Genomic DNA was extracted from sperm cells from a single animal using the GenElute ${ }^{\mathrm{TM}}$ Blood Genomic DNA Kit (Sigma-Aldrich, St. Louis, MO, USA). Genomic DNA amplifications were conducted on an Eppendorf thermocycler as follows: $94{ }^{\circ} \mathrm{C}$ for $2 \mathrm{~min}$, then 4 cycles of $94{ }^{\circ} \mathrm{C}$ for $1 \mathrm{~min}, 53-57^{\circ} \mathrm{C}$ for $1 \mathrm{~min}$ (see Table 2), $72{ }^{\circ} \mathrm{C}$ for $5 \mathrm{~min}$, then 30 cycles of $94^{\circ} \mathrm{C}$ for $30 \mathrm{~s}, 53-57^{\circ} \mathrm{C}$ for $30 \mathrm{~s}, 72{ }^{\circ} \mathrm{C}$ for $5 \mathrm{~min}$, and $72{ }^{\circ} \mathrm{C}$ for $10 \mathrm{~min}$, with Taq DNA Polymerase (Sigma-Aldrich). MT6 and MT7 gene amplicons were obtained amplifying two overlapping fragments (Up and Down).

Amplified genomic fragments were cloned in plasmid vector pGEM-T Easy and MT clones were fully sequenced by primer walking. Sequences were assembled with Codon Code aligner and were annotated using with similarity gene prediction programs and then manually curated.

cDNA and genomic sequences were compared using Wise2DBA (http://www.ebi.ac.uk/Tools/ $\mathrm{psa} /$ wise2dba/) and polyadenylation signal in silico predictions were performed by Poly(A) Signal Miner, at http://dnafsminer.bic.nus.edu.sg/. 
Table 2. Oligonucleotides used as primers for the genomic DNA amplifications.

\begin{tabular}{cccc}
\hline Name & Forward Primer & Reverse Primer & Ta \\
\hline MT4 & TTGGTGATAATAAATGAACCTTGGAG & AGACTGGACAGTATCTAATTGGACAG & 55 \\
MT5 & CAGACAGGTCTCCGTCTCGC & CGCTTCAAGCTCGCCACATT & 57 \\
MT6_UP & CACGGTGTTTTGGTTGATGTC & TTTGTGCATGATGTTCCACAGC & 57 \\
MT6_DW & CACGATTTGTGCTCAATCCTTCAT & CAAGTGCTGGTTGCTATCCTG & 57 \\
MT7_UP & GCATGAGCAAAACCGTAGTCAG & ACATTCTGGATTCTTCTGCGTCG & 53 \\
MT7_DW & TAATGAAACCAGCCCACGATCA & TCACTCCGTCTTTGCAATCTT & 57 \\
MT8a & ATCAGTTACGACGAGAGATCAAATC & TTGGCTATCGCAAGACGTTC & 57 \\
MT8b & AAATGTAAATCAGTGACAGGACG & GAAACAATAAGTCATCAAATAACAAAAC 53 \\
MT8c & CTTCTGAGTCTAGCGTTTCCTTGAAG & CTATCGCAAGACGTTCGTGAGC & 55 \\
\hline \multicolumn{5}{c}{ Ta: annealing temperature. UP: up fragment amplification, DW: down fragment amplification. }
\end{tabular}

\subsection{Sequences and Phylogenetic Analysis}

MT sequences were retrieved from protein databases in NCBI or from the translated nucleotide database. Moreover, many searches both in Expressed Sequence Tag (EST) and Transcriptome Shotgun Assembly (TSA) databases, using TBLASTN software, were performed using both PIMTs and other MT amino acid sequences already annotated as queries. Pam30 matrix and no filter for simple sequences were used as parameters.

EST and TSA sequences were collected, translated using open reading frame (ORF) Finder at NCBI (https:/ / www.ncbi.nlm.nih.gov/orffinder/) or the Translate tool at ExPASy (http:/ / web.expasy. $\mathrm{org} /$ translate/) and tested for the presence of metallothionein domain (UniProt Knowledgebase).

MT protein sequences were aligned with T-Coffee software (http://tcoffee.crg.cat/apps/tcoffee/ index.html) [72] and MSA was used to construct the phylogenetic tree by the neighbour-joining method with PHYLIP software (http:/ / bioweb2.pasteur.fr/docs/phylip/doc/main.html), performing 1000 bootstrap replicates. The outgroup was Tetrahymena pyriformis MT-2 (ABF61447.1) [37], that we already used also in a previous work [25]. Phylogenetic trees were visualized with TreeDyn [73], and MSA was visualized with ESPript (http:/ / espript.ibcp.fr/ESPript/cgi-bin/ESPript.cgi; [74]). MT sequence accession numbers used for alignments are listed in Table 1.

MT genomic sequences already annotated were retrieved from GenBank or from specialized databases. Unannotated MT genes were searched in whole genome shotgun (WGS) contigs or genome databases with BLAST (or BLAT), using transcript sequences as queries (see Table 1). The sequences were submitted to GenBank and will be provided during review.

\subsection{Homology Modelling and Structural Characterization of PlMTs}

The 3D structure of P. lividus homologues were reconstructed by homology modelling via the Phyre 2 software [75], with an intensive modelling mode as reported elsewhere [76,77]. Candidate structures for homology modelling were selected according to pairwise alignment. At least four different structures were used as templates for each generated structure, and homology models were built for all of the sets of proteins. Validation of the structural protein models was performed by assessing the Ramachandran plots. Cycles of clash minimization were also performed for the refinement of structures. Secondary structures assignments and relative solvent accessibility (RSA) were calculated by the DSSP program [78] as implemented in ENDscript, http:/ /endscript.ibcp.fr [74]. 


\subsection{Embryo Cultures, Metal Treatments and Morphological Analysis}

Gametes were collected from gonads of the sea urchin P. lividus, harvested from the West Coast of Sicily. Eggs were fertilized and embryos reared at $18^{\circ} \mathrm{C}$ in millipore-filtered seawater (MFSW) at the dilution of $5000 / \mathrm{mL}$ in glass beakers. In metal-exposure experiments, embryos were continuously cultured after fertilization in the presence of different metal concentrations $\left(\mathrm{ZnCl}_{2}, \mathrm{NiCl}_{2}, \mathrm{PbCl}_{2}\right.$ serial dilutions in MFSW from $10^{-4}$ to $10^{-8} \mathrm{M}$, or $\mathrm{CuSO}_{4}$ from $10^{-5}$ to $10^{-8} \mathrm{M}$ ), and their development was monitored up to $48 \mathrm{~h}$. For total RNA extraction and for WMISH, embryos were collected by low-speed centrifugation at $4{ }^{\circ} \mathrm{C}$ and processed as reported in the respective sections.

Morphological analysis of embryo development was performed after immobilization of embryos with $0.1 \%$ formaldehyde (final concentration) in seawater and observation under an Olympus microscope (OSP-MBI; Olympus, Tokyo, Japan).

\subsection{RNA Extraction and RT-qPCR}

Total RNA was extracted from fertilized eggs and from embryos at 4, 8, 12, 16, 20, 24, 31, 36 and $48 \mathrm{~h}$ of development in MFSW. Moreover, RNA was extracted also from metal-treated P. lividus embryos at the gastrula stage ( $24 \mathrm{~h}$ ) with the RNeasy Mini Kit (Qiagen, Hilden, Germany) following the manufacturer's instructions and performing DNase treatment. The RNA quality assessment, RT-qPCRs were performed as already described in Ragusa et al. [25]. Serial dilutions of cDNA (the standard curve method) permitted to calculate target cDNA starting quantity referred to $18 \mathrm{~S}$ rRNA quantity in arbitrary units (considering $1 \mathrm{AU}$ as $18 \mathrm{~S}$ rRNA/1000).

\subsection{Whole-Mount In Situ Hybridization}

Single strand probes were synthesized from cDNA MTs by asymmetric PCR $[79,80]$ using the PCR DIG Probe Synthesis Kit (Roche). Primers used for probe amplification were designed from full-length coding sequences (Table 3). Probe sequences were aligned with Clustal Omega (http: //www.ebi.ac.uk/Tools/msa/clustalo/) to show differences between them (Figure 14). Embryos were fixed in $2.5 \%$ glutaraldehyde solution on ice for 1-2 $\mathrm{h}$ [59]. Hybridization was performed at $42{ }^{\circ} \mathrm{C}$ $\left(45^{\circ} \mathrm{C}\right.$ for MT8 probe) in hybridization buffer (50\% formamide, $0.6 \mathrm{M} \mathrm{NaCl}, 5 \mathrm{mM}$ EDTA, $20 \mathrm{mM}$ Tris- $\mathrm{HCl} \mathrm{pH} 7.5,2 \times$ Denhardt's, $500 \mu \mathrm{g} / \mathrm{mL}$ yeast tRNA, and $0.1 \%$ Tween-20). Probe concentrations were $0.5-1.0 \mathrm{ng} / \mu \mathrm{L}$. Post-hybridization washes were: hybridization buffer, PBST (PBS, 0.1\% Tween-20), $1 \times$ SSCT $\left(1 \times\right.$ SSC, $0.1 \%$ Tween-20), $0.5 \times$ and $0.2 \times$ SSCT, each $20 \mathrm{~min}$ at $60{ }^{\circ} \mathrm{C}\left(63{ }^{\circ} \mathrm{C}\right.$ for MT8 probe). Subsequently, the antibody incubations were performed out at room temperature with 1:1000 diluted anti-DIG Fab-AP-conjugate (Roche, Basel, Switzerland). The embryos were extensively washed before staining reaction in PBST and twice with alkaline phosphatase (AP) buffer (100 mM Tris- $\mathrm{HCl} \mathrm{pH}$ 9.5, $100 \mathrm{mM} \mathrm{NaCl}, 50 \mathrm{mM} \mathrm{MgCl}$, and $1 \mathrm{mM}$ levamisole, $0.1 \%$ Tween-20). For staining, 5-Bromo-4-chloro-3-indolyl-phosphate (BCIP) and nitro blue tetrazolium were used. Controls were performed using sense probes (data not shown).

Table 3. Primer sets for probe labelling (WMISH).

\begin{tabular}{ccc}
\hline Probe & Forward (Sense) Primer & Reverse (Antisense) Primer \\
\hline MT4 & TAATTTGAACCACGTCTTGAGC & GTTGGCAAACGTCCTTCCTC \\
MT5 & CGACTTTAGCTCAAATTCATCACCATG & GTACAACATCATGTCTCCTCGC \\
$M T 6$ & CACGATTTGTGCTCAATCCTTCAT & TCAATTAATGTAAAACAGCACGGC \\
$M T 7$ & GTAGACCCTGCAGGTAACCG & GCAGCATCTTGGTAGAAGCG \\
$M T 8$ & TGCAGGTTACCCGACAGAAAG & TGTTAGGAGCGACGACAACC \\
\hline
\end{tabular}


1

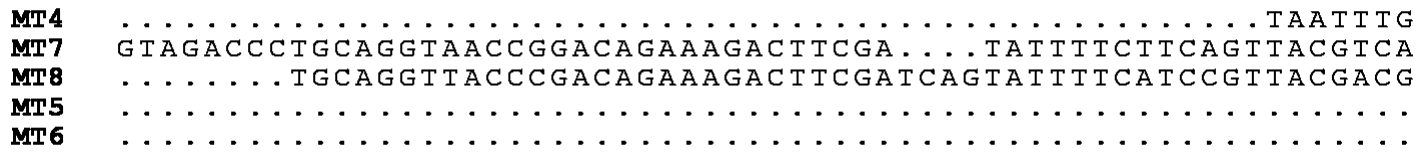

M16

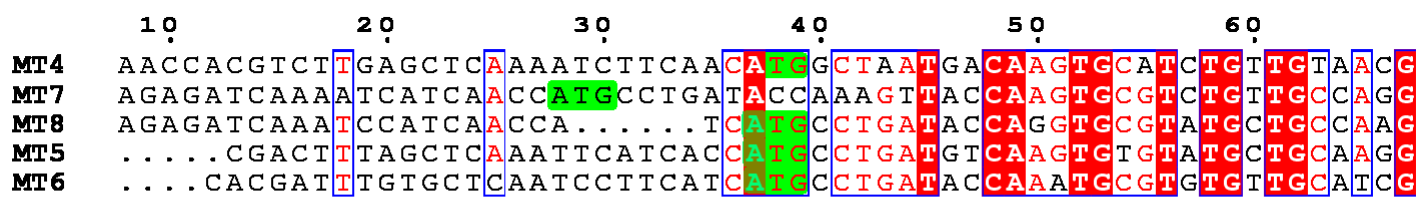

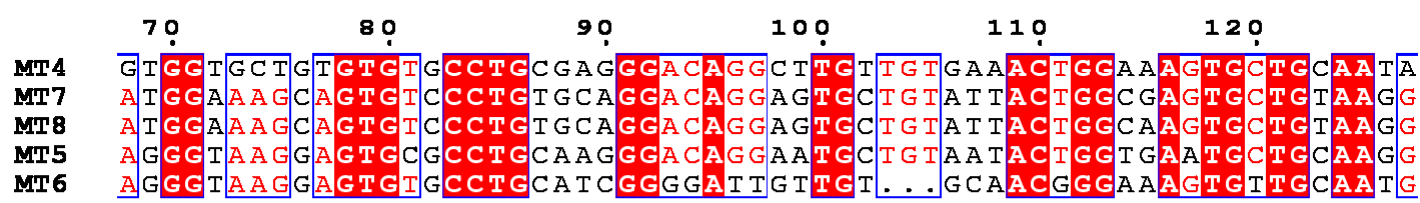

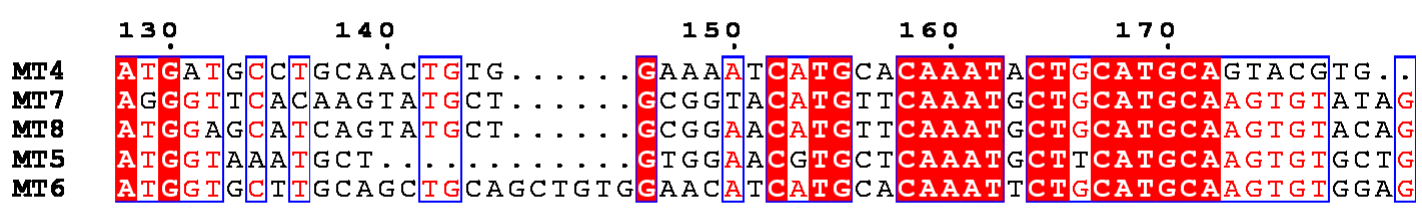

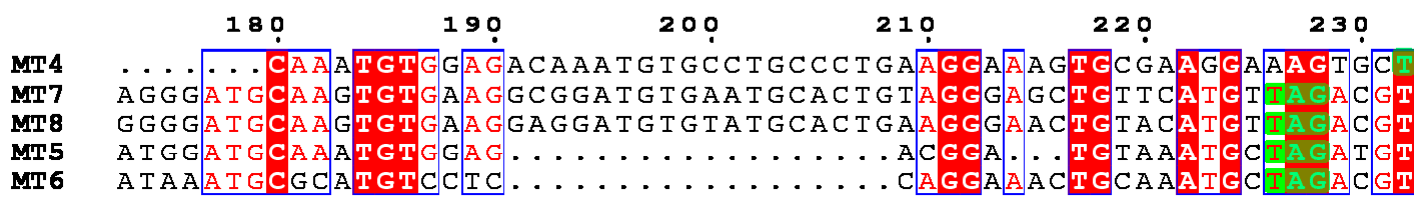
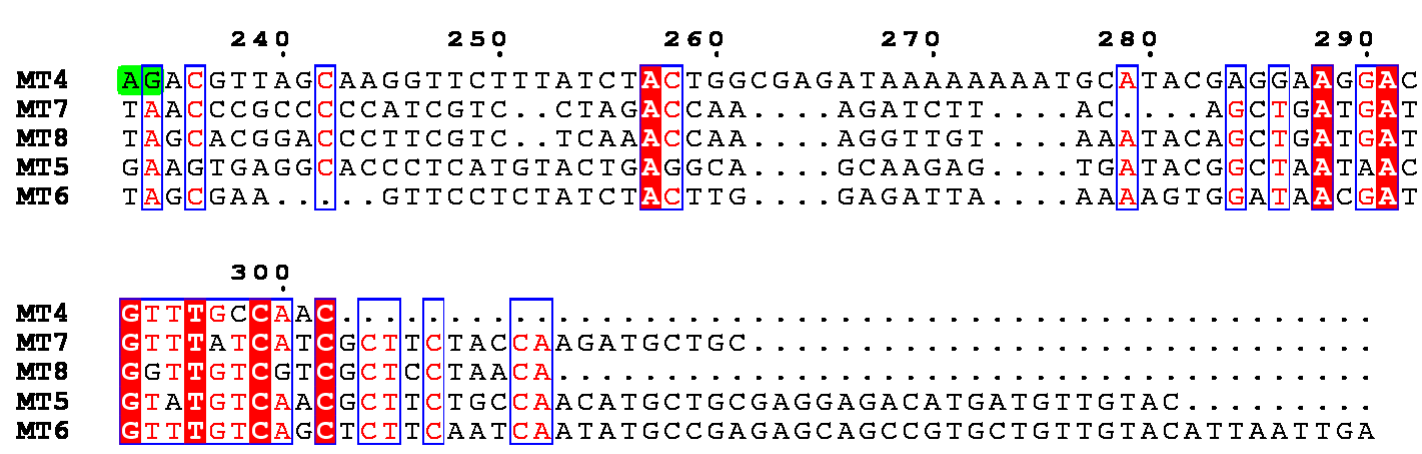

Figure 14. Multiple nucleotide sequence alignment of the probes used in WMISH experiments showing identities (red) and differences (black) among them. Red shading represents identity among all sequences. Dots denote gaps. Start and stop codons are in green.

Acknowledgments: We would like to thank the "sea urchin community" and scientists working in the Phylogenetic Analysis of Echinoderms BioProject for the sequences. This work was supported by the Università degli Studi di Palermo FFR-EX60\% (grant number 3098/2012 to M.A.R.) and the CISAS Research Program (to A.C).

Author Contributions: Maria Antonietta Ragusa and Fabrizio Gianguzza conceived and designed the experiments; Maria Antonietta Ragusa and Salvatore Costa performed the experiments; Maria Antonietta Ragusa, Fabrizio Gianguzza, Salvatore Costa, and Aldo Nicosia analysed the data; Maria Antonietta Ragusa and Angela Cuttitta contributed reagents/materials/analysis tools; Maria Antonietta Ragusa and Fabrizio Gianguzza wrote the paper.

Conflicts of Interest: The authors declare no conflict of interest. The founding sponsors had no role in the design of the study; in the collection, analyses, or interpretation of data; in the writing of the manuscript, and in the decision to publish the results. 


\section{Abbreviations}

$\begin{array}{ll}\text { EST } & \text { Expressed sequence tags } \\ \text { MFSW } & \text { Millipore filtered sea water } \\ \text { MSA } & \text { Multiple sequence alignment } \\ \text { Myr } & \text { Million years ago } \\ \text { PIMTs } & \text { Paracentrotus lividus metallothioneins } \\ \text { PMCs } & \text { Primary mesenchyme cells } \\ \text { RSA } & \text { Relative solvent accessibility } \\ \text { RT-qPCR } & \text { Reverse transcription and quantitative (real time) PCR } \\ \text { SpMTs } & \text { Strongylocentrotus purpuratus metallothioneins } \\ \text { TSS } & \text { Transcription start site } \\ \text { WGS } & \text { Whole genome shotgun } \\ \text { WMISH } & \text { Whole-mount in situ hybridization }\end{array}$

\section{References}

1. Braun, W.; Wagner, G.; Wörgötter, E.; Vasák, M.; Kägi, J.H.; Wüthrich, K. Polypeptide fold in the two metal clusters of metallothionein-2 by nuclear magnetic resonance in solution. J. Mol. Biol. 1986, 187, 125-129. [CrossRef]

2. Kumari, M.V.; Hiramatsu, M.; Ebadi, M. Free radical scavenging actions of metallothionein isoforms I and II. Free Radic. Res. 1998, 29, 93-101. [CrossRef] [PubMed]

3. Macirella, R.; Guardia, A.; Pellegrino, D.; Bernabò, I.; Tronci, V.; Ebbesson, L.O.E.; Sesti, S.; Tripepi, S.; Brunelli, E. Effects of two sublethal concentrations of mercury chloride on the morphology and metallothionein activity in the liver of zebrafish (Danio rerio). Int. J. Mol. Sci. 2016, 17. [CrossRef] [PubMed]

4. Ling, X.B.; Wei, H.W.; Wang, J.; Kong, Y.Q.; Wu, Y.Y.; Guo, J.L.; Li, T.F.; Li, J.K. Mammalian metallothionein-2A and oxidative stress. Int. J. Mol. Sci. 2016, 17. [CrossRef] [PubMed]

5. Capdevila, M.; Bofill, R.; Palacios, Ò.; Atrian, S. State-of-the-art of metallothioneins at the beginning of the 21st century. Coord. Chem. Rev. 2012, 256, 46-62. [CrossRef]

6. Jin, R.; Chow, V.T.K.; Tan, P.H.; Dheen, S.T.; Duan, W.; Bay, B.H. Metallothionein 2A expression is associated with cell proliferation in breast cancer. Carcinogenesis 2002, 23, 81-86. [CrossRef] [PubMed]

7. Apostolova, M.D.; Ivanova, I.A.; Cherian, M.G. Metallothionein and apoptosis during differentiation of myoblasts to myotubes: Protection against free radical toxicity. Toxicol. Appl. Pharmacol. 1999, 159, 175-184. [CrossRef] [PubMed]

8. Cherian, M.G.; Apostolova, M.D. Nuclear localization of metallothionein during cell proliferation and differentiation. Cell. Mol. Biol. 2000, 46, 347-356. [PubMed]

9. Shimoda, R.; Achanzar, W.E.; Qu, W.; Nagamine, T.; Takagi, H.; Mori, M.; Waalkes, M.P. Metallothionein is a potential negative regulator of apoptosis. Toxicol. Sci. 2003, 73, 294-300. [CrossRef] [PubMed]

10. Wu, C.; Pot, C.; Apetoh, L.; Thalhamer, T.; Zhu, B.; Murugaiyan, G.; Xiao, S.; Lee, Y.; Rangachari, M.; Yosef, N.; Kuchroo, V.K. Metallothioneins negatively regulate IL-27-induced type 1 regulatory T-cell differentiation. Proc. Natl. Acad. Sci. USA 2013, 110, 7802-7807. [CrossRef] [PubMed]

11. Heger, Z.; Rodrigo, M.A.M.; Krizkova, S.; Ruttkay-Nedecky, B.; Zalewska, M.; del Pozo, E.M.P.; Pelfrene, A.; Pourrut, B.; Stiborova, M.; Eckschlager, T.; et al. Metallothionein as a scavenger of free radicals-New cardioprotective therapeutic agent or initiator of tumor chemoresistance? Curr. Drug Targets 2016, 17, 1438-1451. [CrossRef] [PubMed]

12. Lynes, M.A.; Hidalgo, J.; Manso, Y.; Devisscher, L.; Laukens, D.; Lawrence, D.A. Metallothionein and stress combine to affect multiple organ systems. Cell Stress Chaperones 2014, 19, 605-611. [CrossRef] [PubMed]

13. Raudenska, M.; Gumulec, J.; Podlaha, O.; Sztalmachova, M.; Babula, P.; Eckschlager, T.; Adam, V.; Kizek, R.; Masarik, M. Metallothionein polymorphisms in pathological processes. Metallomics 2014, 6, 55-68. [CrossRef] [PubMed]

14. Werynska, B.; Pula, B.; Kobierzycki, C.; Dziegiel, P.; Podhorska-Okolow, M. Metallothioneins in the lung cancer. Folia Histochem. Cytobiol. 2015, 53, 1-10. [CrossRef] [PubMed]

15. Yu, W.H.; Lukiw, W.J.; Bergeron, C.; Niznik, H.B.; Fraser, P.E. Metallothionein III is reduced in Alzheimer's disease. Brain Res. 2001, 894, 37-45. [CrossRef] 
16. Binz, P.-A.; Kägi, J.H.R. Metallothionein: Molecular Evolution and Classification, In Metallothionein IV, Advances in Life Sciences; Klaassen, C.D., Ed.; Birkhäuser: Basel, Switzerland, 1999; pp. 7-13.

17. Capdevila, M.; Atrian, S. Metallothionein protein evolution: A miniassay. J. Biol. Inorg. Chem. 2011, 16, 977-989. [CrossRef] [PubMed]

18. Palacios, O.; Atrian, S.; Capdevila, M. Zn- and Cu-thioneins: A functional classification for metallothioneins? J. Biol. Inorg. Chem. 2011, 16, 991-1009. [CrossRef] [PubMed]

19. Palacios, Ò.; Pagani, A.; Pérez-Rafael, S.; Egg, M.; Höckner, M.; Brandstätter, A.; Capdevila, M.; Atrian, S.; Dallinger, R. Shaping mechanisms of metal specificity in a family of metazoan metallothioneins: Evolutionary differentiation of mollusc metallothioneins. BMC Biol. 2011, 9, 4. [CrossRef] [PubMed]

20. Jenny, M.J.; Payton, S.L.; Baltzegar, D.A.; Lozier, J.D. Phylogenetic analysis of molluscan metallothioneins: Evolutionary insight from Crassostrea virginica. J. Mol. Evol. 2016, 83, 110-125. [CrossRef] [PubMed]

21. Nemer, M.; Wilkinson, D.G.; Travaglini, E.C.; Sternberg, E.J.; Butt, T.R. Sea urchin metallothionein sequence: Key to an evolutionary diversity. Proc. Natl. Acad. Sci. USA 1985, 82, 4992-4994. [CrossRef] [PubMed]

22. Cserjesi, P.; Fang, H.; Brandhorst, B.P. Metallothionein gene expression in embryos of the sea urchin Lytechinus pictus. Mol. Reprod. Dev. 1997, 47, 39-46. [CrossRef]

23. Scudiero, R.; Capasso, C.; Carginale, V.; Riggio, M.; Capasso, A.; Ciaramella, M.; Filosa, S.; Parisi, E. PCR amplification and cloning of metallothionein complementary DNAs in temperate and Antarctic sea urchin characterized by a large difference in egg metallothionein content. Cell. Mol. Life Sci. 1997, 53, 472-477. [CrossRef] [PubMed]

24. Riek, R.; Prêcheur, B.; Wang, Y.; Mackay, E.A.; Wider, G.; Güntert, P.; Liu, A.; Kägi, J.H.; Wüthrich, K. NMR structure of the sea urchin (Strongylocentrotus purpuratus) metallothionein MTA. J. Mol. Biol. 1999, 291, 417-428. [CrossRef] [PubMed]

25. Ragusa, M.A.; Costa, S.; Gianguzza, M.; Roccheri, M.C.; Gianguzza, F. Effects of cadmium exposure on sea urchin development assessed by SSH and RT-qPCR: Metallothionein genes and their differential induction. Mol. Biol. Rep. 2013, 40, 2157-2167. [CrossRef] [PubMed]

26. Smith, A.B. Phylogenetic relationship, divergence times, and rates of molecular evolution for Camarodont sea urchin. Mol. Biol. Evol. 1988, 5, 345-365.

27. Goldstone, J.V.; Hamdoun, A.; Cole, B.J.; Howard-Ashby, M.; Nebert, D.W.; Scally, M.; Dean, M.; Epel, D.; Hahn, M.E.; Stegeman, J.J. The chemical defensome: Environmental sensing and response genes in the Strongylocentrotus purpuratus genome. Dev. Biol. 2006, 300, 366-384. [CrossRef] [PubMed]

28. Franchi, N.; Boldrin, F.; Ballarin, L.; Piccinni, E. CiMT-1, an unusual chordate metallothionein gene in Ciona intestinalis genome: Structure and expression studies. J. Exp. Zool. A Ecol. Genet. Physiol. 2011, 315A, 90-100. [CrossRef] [PubMed]

29. Yamaguchi, N.; Kamino, K.; Ueki, T.; Michibata, H. Expressed sequence tag analysis of vanadocytes in a vanadium-rich ascidian, Ascidia sydneiensis samea. Mar. Biotechnol. 2004, 6, 165-174. [CrossRef] [PubMed]

30. Guirola, M.; Pérez-Rafael, S.; Capdevila, M.; Palacios, O.; Atrian, S. Metal dealing at the origin of the Chordata phylum: The metallothionein system and metal overload response in amphioxus. PLoS ONE 2012, 7, e43299. [CrossRef] [PubMed]

31. Kim, J.H.; Wang, S.Y.; Kim, I.C.; Ki, J.S.; Raisuddin, S.; Lee, J.S.; Han, K.N. Cloning of a river pufferfish (Takifugu obscurus) metallothionein cDNA and study of its induction profile in cadmium-exposed fish. Chemosphere 2008, 71, 1251-1259. [CrossRef] [PubMed]

32. Wu, S.M.; Zheng, Y.D.; Kuo, C.H. Expression of MT2 and SMT-B upon cadmium exposure and cold shock in zebrafish (Danio rerio). Comp. Biochem. Physiol. C Toxicol. Pharmacol. 2008, 148, 184-193. [CrossRef] [PubMed]

33. Santovito, G.; Formigari, A.; Boldrin, F.; Piccinni, E. Molecular and functional evolution of Tetrahymena metallothioneins: New insights into the gene family of Tetrahymena thermophila. Comp. Biochem. Physiol. C Toxicol. Pharmacol. 2007, 144, 391-397. [CrossRef] [PubMed]

34. Domènech, J.; Bofill, R.; Tinti, A.; Torreggiani, A.; Atrian, S.; Capdevila, M. Comparative insight into the $\mathrm{Zn}(\mathrm{II})-, \mathrm{Cd}(\mathrm{II})-$ and $\mathrm{Cu}(\mathrm{I})$-binding features of the protozoan Tetrahymena pyriformis MT1 metallothionein. Biochim. Biophys. Acta 2008, 1784, 693-704. [CrossRef] [PubMed]

35. De Francisco, P.; Melgar, L.M.; Díaz, S.; Martín-González, A.; Gutiérrez, J.C. The Tetrahymena metallothionein gene family: Twenty-one new cDNAs, molecular characterization, phylogenetic study and comparative analysis of the gene expression under different abiotic stressors. BMC Genom. 2016, 17, 346. [CrossRef] [PubMed] 
36. Piccinni, E.; Staudenmann, W.; Albergoni, V.; de Gabrieli, R.; James, P. Purification and primary structure of metallothioneins induced by cadmium in the protists Tetrahymena pigmentosa and Tetrahymena pyriformis. Eur. J. Biochem. 1994, 226, 853-859. [CrossRef] [PubMed]

37. Piccinni, E.; Bertaggia, D.; Santovito, G.; Miceli, C.; Kraev, A. Cadmium metallothionein gene of Tetrahymena pyriformis. Gene 1999, 234, 51-59. [CrossRef]

38. Fu, C.; Miao, W. Cloning and characterization of a new multi-stress inducible metallothionein gene in Tetrahymena pyriformis. Protist 2006, 157, 193-203. [CrossRef] [PubMed]

39. Smith, A.B.; Pisani, D.; Mackenzie-Dodds, J.A.; Stockley, B.; Webster, B.L.; Littlewood, D.T.J. Testing the molecular clock: Molecular and paleontological estimates of divergence times in the Echinoidea (Echinodermata). Mol. Biol. Evol. 2006, 23, 1832-1851. [CrossRef] [PubMed]

40. Peterson, K.J.; Eernisse, D.J. The phylogeny, evolutionary developmental biology, and paleobiology of the Deuterostomia: 25 years of new techniques, new discoveries, and new ideas. Org. Divers. Evol. 2016, 16, 401-418. [CrossRef]

41. Quiniou, F.; Guillou, M.; Judas, A. Arrest and delay in embryonic development in sea urchin populations of the Bay of Brest (Brittany, France); link with environmental factors. Mar. Pollut. Bull. 1999, 38, 401-406. [CrossRef]

42. Guillou, B.; Quiniou, E.; Huart, B.; Pagano, G. Comparison of embryonic development and metal contamination in several populations of the sea urchin Sphaerechinus granularis (Lamarck) exposed to anthropogenic pollution. Arch. Environ. Contam. Toxicol. 2000, 39, 337-344. [CrossRef] [PubMed]

43. Fernández, N.; Beiras, R. Combined toxicity of dissolved mercury with copper, lead and cadmium on embryogenesis and early larval growth of the Paracentrotus lividus sea-urchin. Ecotoxicology 2001, 10, $263-271$. [CrossRef] [PubMed]

44. King, C.K.; Riddle, M.J. Effects of metal contaminants on the development of the common Antarctic sea urchin Sterechinus neumayeri and comparisons of sensitivity with tropical and temperate echinoids. Mar. Ecol. Prog. Ser. 2001, 215, 143-154. [CrossRef]

45. Kobayashi, N.; Okamura, H. Effects of heavy metals on sea urchin embryo development. 1. Tracing the cause by the effects. Chemosphere 2004, 55, 1403-1412. [CrossRef] [PubMed]

46. Kobayashi, N.; Okamura, H. Effects of heavy metals on sea urchin embryo development. Part 2. Interactive toxic effects of heavy metals in synthetic mine effluents. Chemosphere 2005, 61, 1198-1203. [CrossRef] [PubMed]

47. Waterman, A.J. Effect of salts of heavy metals on development of the sea urchin, Arbacia punctulata. Biol. Bull. 1937, 73, 401-420. [CrossRef]

48. Torres-Duarte, C.; Adeleye, A.S.; Pokhrel, S.; Mädler, L.; Keller, A.A.; Cherr, G.N. Developmental effects of two different copper oxide nanomaterials in sea urchin (Lytechinus pictus) embryos. Nanotoxicology 2016, 10, 671-679. [CrossRef] [PubMed]

49. Hardin, J.; Coffman, J.A.; Black, S.D.; McClay, D.R. Commitment along the dorsoventral axis of the sea urchin embryo is altered in response to NiCl2. Development 1992, 116, 671-685. [PubMed]

50. Armstrong, N.; Hardin, J.; McClay, D.R. Cell-cell interactions regulate skeleton formation in the sea urchin embryo. Development 1993, 119, 833-840. [PubMed]

51. Manzo, S.; Buono, S.; Cremisini, C. Cadmium, lead and their mixtures with copper: Paracentrotus lividus embryotoxicity assessment, prediction, and offspring quality evaluation. Ecotoxicology 2010, 19, 1209-1223. [CrossRef] [PubMed]

52. Radenac, G.; Fichet, D.; Miramand, P. Bioaccumulation and toxicity of four dissolved metals in Paracentrotus lividus sea-urchin embryo. Mar. Environ. Res. 2001, 51, 151-166. [CrossRef]

53. Scudiero, R.; Capasso, C.; del Vecchio-Blanco, F.; Savino, G.; Capasso, A.; Parente, A.; Parisi, E. Isolation and primary structure determination of a metallothionein from Paracentrotus lividus (Echinodermata, Echinoidea). Comp. Biochem. Physiol. Part B Biochem. Mol. Biol. 1995, 111, 329-336. [CrossRef]

54. Russo, R.; Bonaventura, R.; Zito, F.; Schröder, H.C.; Müller, I.; Müller, W.E.G.; Matranga, V. Stress to cadmium monitored by metallothionein gene induction in Paracentrotus lividus embryos. Cell Stress Chaperones 2003, 8, 232-241. [CrossRef]

55. Stetefeld, J.; Ruegg, M.A. Structural and functional diversity generated by alternative mRNA splicing. Trends Biochem. Sci. 2005, 30, 515-521. [CrossRef] [PubMed] 
56. Jeffares, D.C.; Penkett, C.J.; Bähler, J. Rapidly regulated genes are intron poor. Trends Genet. 2008, 24, 375-378. [CrossRef] [PubMed]

57. Smith, A.B.; Peterson, K.J.; Wray, G.; Littlewood, D.T.J. From bilateral symmetry to pentaradiality: The phylogeny of hemichordates and echinoderms. In B Assembling the Tree of Life; Cracraft, J., Donoghue, M.J., Eds.; Oxford University Press: Oxford, UK, 2004; pp. 365-383.

58. Russo, R.; Zito, F.; Matranga, V. Tissue-specificity and phylogenetics of Pl-MT mRNA during Paracentrotus lividus embryogenesis. Gene 2013, 519, 305-310. [CrossRef] [PubMed]

59. Harkey, M.A.; Whiteley, H.R.; Whiteley, A.H. Differential expression of the msp130 gene among skeletal lineage cells in the sea urchin embryo: A three dimensional in situ hybridization analysis. Mech. Dev. 1992, 37, 173-184. [CrossRef]

60. Viarengo, A. Heavy metals in marine invertebrates: Mechanisms of regulation and toxicity at the cellular level. Aquat. Sci. 1989, 1, 295-317.

61. Chiarelli, R.; Agnello, M.; Bosco, L.; Roccheri, M.C. Sea urchin embryos exposed to cadmium as an experimental model for studying the relationship between autophagy and apoptosis. Mar. Environ. Res. 2014, 93, 47-55. [CrossRef] [PubMed]

62. Tellis, M.S.; Lauer, M.M.; Nadella, S.; Bianchini, A.; Wood, C.M. Sublethal mechanisms of Pb and Zn toxicity to the purple sea urchin (Strongylocentrotus purpuratus) during early development. Aquat. Toxicol. 2014, 146, 220-229. [CrossRef] [PubMed]

63. Beniash, E.; Aizenberg, J.; Addadi, L.; Weiner, S. Amorphous calcium carbonate transforms into calcite during sea urchin larval spicule growth. Proc. Biol. Sci. 1997, 264, 461-465. [CrossRef]

64. Vidavsky, N.; Addadi, S.; Mahamid, J.; Shimoni, E.; Ben-Ezra, D.; Shpigel, M.; Weiner, S.; Addadi, L. Initial stages of calcium uptake and mineral deposition in sea urchin embryos. Proc. Natl. Acad. Sci. USA 2014, 111, 39-44. [CrossRef] [PubMed]

65. Wilkinson, D.G.; Nemer, M. Metallothionein genes MTa and MTb expressed under distinct quantitative and tissue-specific regulation in sea urchin embryos. Mol. Cell. Biol. 1987, 7, 48-58. [CrossRef] [PubMed]

66. Angerer, L.M.; Kawczynski, G.; Wilkinson, D.G.; Nemer, M.; Angerer, R.C. Spatial patterns of metallothionein mRNA expression in the sea urchin embryo. Dev. Biol. 1986, 116, 543-547. [CrossRef]

67. Varrella, S.; Romano, G.; Ianora, A.; Bentley, M.G.; Ruocco, N.; Costantini, M. Molecular response to toxic diatom-derived aldehydes in the sea urchin Paracentrotus lividus. Mar. Drugs 2014, 12, 2089-2113. [CrossRef] [PubMed]

68. Varrella, S.; Romano, G.; Ruocco, N.; Ianora, A.; Bentley, M.G.; Costantini, M. First morphological and molecular evidence of the negative impact of diatom-derived hydroxyacids on the sea urchin Paracentrotus lividus. Toxicol. Sci. 2016, 151, 419-433. [CrossRef] [PubMed]

69. Migliaccio, O.; Castellano, I.; Romano, G.; Palumbo, A. Stress response to cadmium and manganese in Paracentrotus lividus developing embryos is mediated by nitric oxide. Aquat. Toxicol. 2014, 156, 125-134. [CrossRef] [PubMed]

70. Migliaccio, O.; Castellano, I.; Cirino, P.; Romano, G.; Palumbo, A. Maternal exposure to cadmium and manganese impairs reproduction and progeny fitness in the sea urchin Paracentrotus lividus. PLoS ONE 2015, 10, e0131815. [CrossRef] [PubMed]

71. Altschul, S.F.; Madden, T.L.; Schäffer, A.A.; Zhang, J.; Zhang, Z.; Miller, W.; Lipman, D.J. Gapped BLAST and PSI-BLAST: A new generation of protein database search programs. Nucleic Acids Res. 1997, 25, 3389-3402. [CrossRef] [PubMed]

72. Notredame, C.; Higgins, D.G.; Heringa, J. T-Coffee: A novel method for fast and accurate multiple sequence alignment. J. Mol. Biol. 2000, 302, 205-217. [CrossRef] [PubMed]

73. Chevenet, F.; Brun, C.; Bañuls, A.L.; Jacq, B.; Christen, R. TreeDyn: Towards dynamic graphics and annotations for analyses of trees. BMC Bioinform. 2006, 7, 439. [CrossRef] [PubMed]

74. Robert, X.; Gouet, P. Deciphering key features in protein structures with the new ENDscript server. Nucleic Acids Res. 2014, 42, W320-W324. [CrossRef] [PubMed]

75. Kelley, L.A.; Mezulis, S.; Yates, C.M.; Wass, M.N.; Sternberg, M.J.E. The Phyre2 web portal for protein modeling, prediction and analysis. Nat. Protoc. 2015, 10, 845-858. [CrossRef] [PubMed]

76. Nicosia, A.; Maggio, T.; Costa, S.; Salamone, M.; Tagliavia, M.; Mazzola, S.; Gianguzza, F.; Cuttitta, A. Maintenance of a protein structure in the dynamic evolution of TIMPs over 600 million years. Genome Biol. Evol. 2016, 8, 1056-1071. [CrossRef] [PubMed] 
77. Salamone, M.; Nicosia, A.; Bennici, C.; Quatrini, P.; Catania, V.; Mazzola, S.; Ghersi, G.; Cuttitta, A. Comprehensive analysis of a Vibrio parahaemolyticus strain extracellular serine protease VpSP37. PLoS ONE 2015, 10, e0126349. [CrossRef] [PubMed]

78. Kabsch, W.; Sander, C. Dictionary of protein secondary structure: Pattern recognition of hydrogen-bonded and geometrical features. Biopolymers 1983, 22, 2577-2637. [CrossRef] [PubMed]

79. Gianguzza, F.; Casano, C.; Ragusa, M. $\alpha$-tubulin marker gene of neural territory of sea urchin embryos detected by whole-mount in situ hybridization. Int. J. Dev. Biol. 1995, 39, 477-483. [PubMed]

80. Casano, C.; Ragusa, M.; Cutrera, M.; Costa, S.; Gianguzza, F. Spatial expression of $\alpha$ and $\beta$ tubulin genes in the late embryogenesis of the sea urchin Paracentrotus lividus. Int. J. Dev. Biol. 1996, 40, 1033-1041. [PubMed]

(C) 2017 by the authors. Licensee MDPI, Basel, Switzerland. This article is an open access article distributed under the terms and conditions of the Creative Commons Attribution (CC BY) license (http:/ / creativecommons.org/licenses/by/4.0/). 